\title{
EMPODERAMIENTO EN LA COMUNIDAD. EL DISEÑO DE UN SISTEMA ABIERTO DE INDICADORES A PARTIR DE PROCESOS DE EVALUACIÓN PARTICIPATIVA
}

\section{EMPOWERMENT IN THE COMMUNITY. THE DESIGN OF AN OPEN INDICATORS SYSTEM FROM PARTICIPATORY EVALUATION PROCESSES}

\section{EMPODERAMENTO NA COMUNIDADE. O DESENHO DE UM CONJUNTO ABERTO DE INDICADORES A PARTIR DE PROCESSOS DE AVALIAÇÃO PARTICIPATIVA}

\author{
Pere Soler y Anna Planas \\ UNIVERSIDAD DE GIRONA, ESPAÑA
}

\section{Anna Ciraso-Calí y Arantxa Ribot-Horas}

Universidad Autónoma de Barcelona, España

\begin{abstract}
RESUMEN: Existen numerosas perspectivas y aproximaciones conceptuales a la Evaluación Participativa (EP) y a los significados y sentidos que esta puede tener. En todos los casos, supone un cambio de perspectiva en los modelos de evaluación, planteándose como un proceso de aprendizaje individual y colectivo. En las siguientes líneas se pretende avanzar en averiguar de qué manera los aprendizajes generados en procesos de EP contribuyen al empoderamiento de las personas y comunidades que protagonizan dicha evaluación. La aportación que aquí se presenta describe el diseño y ensayo de un sistema abierto de indicadores de empoderamiento que pretende evidenciar el aprendizaje que procesos como la EP generan en las personas que los viven. A través del análisis de la literatura y la discusión con investigadores, técnicos y agentes comunitarios, se detectan variables e indicadores de empoderamiento. Estos indicadores se ensayan en tres estudios de caso que nos permiten comprobar su utilidad. Para ello se aplican cuestionarios, el análisis de contenido de las actas y transcripciones de las sesiones de EP y la realización de entrevistas semiestructuradas a los miembros de los grupos de EP. Se presenta el listado general de variables e indicadores de empoderamiento, entendido como un sistema abierto, como una matriz generadora, en la medida que puede completarse y contrastarse a partir de las nuevas aportaciones que surjan con su aplicación. A partir de la contrastación bibliográfica, se han validado la mayoría de indicadores propuestos. El sistema además propone indicadores poco habituales en las formulaciones realizadas hasta ahora, pero que en esta propuesta han sido validados a través de los estudios de caso. Se considera el material presentado como
\end{abstract}


un buen punto de partida para posteriores investigaciones y una ayuda para reforzar enormemente el discurso y el valor de las acciones socioeducativas y el trabajo comunitario.

PALABRAS CLAVE: Empoderamiento; Evaluación empoderadora; indicadores de evaluación; planes comunitarios; acción comunitaria.

ABSTRACT: There are several perspectives and conceptual approaches to Participatory Evaluation (PE) and the meanings and senses that it may have. In all cases, it involves a new point of view among assessment models, as it is considered itself as a process of individual and collective learning. In this article we aim to deepen in this topic; and to find out how this learning contributes to the empowerment of individuals and communities who are lead this evaluation. This paper describes the design and testing of an open indicators system to highlight empowerment, which aims to show the learning that EP processes generate in the people who experience it. Variables and indicators of empowerment are identified through literature analysis and discussion with researchers, technicians and community workers... These indicators are tested on three case studies, which allow verifying its utility. In these case studies we used questionnaires, content analysis of minutes and transcriptions of community sessions and semi-structured interviews to members of EP groups. We present the general list of variables and indicators of empowerment, understood as an open system, as a generator matrix, which can be completed and contrasted from the new contributions arisen during its application. From the literature analysis, most of our proposed indicators were confirmed. The system also includes some unusual indicators in formulations made so far, but that have been validated through our case studies. We consider that this contribution is a good starting point for further research, and a help to greatly enhance the discourse and the value of socio-educational actions and community work.

KEYWORDS: Empowerment; empowerment evaluation; evaluation indicators; community plans; community development.

RESUMO: Existem inúmeras perspectivas e abordagens conceituais para Avaliação Participativa (AP) e os significados e sentidos que esta pode ter. Em todos os casos envolve uma mudança de perspectiva em modelos de avaliação, considerando-se como um processo de aprendizagem individual e coletivo. Nas seguintes linhas se pretende avançar em averiguar de que maneira as aprendizagens geradas em processo de AP contribuem para o empoderamento das pessoas e comunidades que protagonizam tal avaliação. A contribuição que aqui se apresenta descreve o desenho e ensaio de um sistema aberto de indicadores de empoderamento que pretende evidenciar a aprendizagem que processos como a AP geram nas pessoas que a vivenciam. Se detectam variáveis e indicadores de empoderamento através da análise da literatura e a discussão com investigadores, técnicos e agentes comunitários. Estes indicadores são testados em três estudos de caso que nos permitem testar a sua utilidade: através de um questionário, da análise de conteúdo das atas e transcrições das sessões de AP e da realização de entrevistas semi-estruturadas aos membros dos grupos de AP. Se apresenta a lista geral de variáveis e indicadores de empoderamento entendido como um sistema aberto, como uma matriz geradora, na medida em que pode completar-se e contrastarse a partir das novas contribuições que surjam com a sua aplicação. A partir da contrastação bibliográfica foi validado a maioria dos indicadores propostos. O sistema propõe outros indicadores pouco habituais nas formulações realizadas até agora, mas foram validados através de estudos de caso. O material apresentado é considerado como um bom ponto de partida para futuras pesquisas, e uma ajuda para reforçar enormemente o discurso e o valor das ações socioeducativas e o trabalho comunitário.

PALAVRAS-CHAVE: Empoderamento; Avaliação empoderadora; indicadores de avaliação; planos comunitários; ação comunitária.

[50 ] PERE SOLER, ANNA PLANAS, ANNA CIRASO-CALÍ Y ARANTXA RIBOT-HORAS

SIPS - PEDAGOGIA SOCIAL. REVISTA INTERUNIVERSITARIA [1139-1723 (2014) 24, 49-77] TERCERA ÉPOCA 


\section{Introducción}

La Evaluación Participativa (EP) supone un cambio de perspectiva en los modelos de evaluación de programas, sobre todo en los focalizados sobre acciones socioeducativas, formativas y culturales dentro del ámbito comunitario. $L$ a EP se plantea en estas prácticas más como un proceso de aprendizaje individual y colectivo, que puede contribuir al empoderamiento, que como una forma de control; aunque, tal como apuntan Suárez-Balcazar y Harper (2004), no todas las evaluaciones participativas son empoderadoras, sino sólo aquellas que se focalizan sobre la transferencia de habilidades y la construcción de la capacidad de evaluación de sus participantes.

El objetivo de este artículo es aportar una nueva herramienta en el ámbito del estudio del empoderamiento individual y comunitario, que pueda ser de utilidad para valorar el carácter empoderador de las Evaluaciones Participativas. Para ello en primer lugar se presenta el análisis de las principales aportaciones de las investigaciones de EP realizadas en los últimos diez años. Posteriormente se presentan los instrumentos, creados por el equipo de investigación y basados en una primera propuesta de indicadores, para la recogida de información sobre los aprendizajes que realizan las personas participantes en procesos de EP en tres estudios de caso. Finalmente se propone un sistema de indicadores de empoderamiento individual y comunitario que nos permita evidenciar y concretar cómo podemos detectar si nuestras acciones y proyectos van en esta dirección.

Este artículo se contextualiza en un proyecto interuniversitario de investigación centrado en las acciones comunitarias, la EP y el empoderamiento personal y comunitario'. Para más información sobre la investigación, se puede consultar Úcar, Heras y Soler (2014).

\section{Marco teórico}

\subsection{Empoderamiento}

La configuración del concepto de empoderamiento en la sociedad civil tiene lugar a partir de los años 60 y con su uso y difusión se detectan distintas orien-

\section{Introduction}

The Participatory Evaluation (PE) means a change in the evaluation program model's approach, mainly in those focused on socio-educational, training and cultural actions into the community field. With these practices, the PE is presented more as an individual and collective learning process, which can contribute to empowerment, than as a control method; even though, as Suárez-Balcazar and Harper (2004) pointed out, not all the participatory evaluations empower but only those focused on the abilities' transference and on the build of an evaluation capacity of their participants.

The aim of this paper is to provide with a new tool in the individual and community empowerment study, which helps to appreciate the empowerment side of the Participatory Evaluations. In order to make it possible, it starts with an analysis of PE's main contributions of the last ten years. Secondly, it presents the tools created by the research team (based on an initial proposal of indicators) in order to collect the learning information made by the participant in PE processes in the three case studies. Finally, an individual and community empowerment indicator system is proposed, that enable us to make clear and set how can we figure out whether our actions and projects go in this direction or not.

This paper is framed in an interuniversity research project based on community actions, the PE and the personal and community empowerment ${ }^{2}$. For more information about the research Úcar, Heras and Soler (2014) can be consulted.

\section{Theoretical framework}

\subsection{Empowerment}

The configuration of the empowerment concept in a civil society arose in the 60's and several orientations were detected when using and dissemina- 
taciones, según el discurso o perspectiva de análisis (pedagógica, psicológica, sociológica, económica, etc.). Entre los autores que han profundizado en este término hay que mencionar las aportaciones desde la psicología comunitaria y entre ellas los trabajos de Rappaport (1981, 1985, 1986, 1987), según el cual el objetivo de la teoría en psicología comunitaria no es otro que el empoderamiento. Al mismo tiempo, la propia etimología de empoderamiento nos remite a los estudios sobre las distintas modalidades y enfoques de este término. El concepto de empoderamiento, argumenta Rowlands (1997, p.13), se entiende de manera diferente dentro de cada interpretación de poder; donde se enlazan además distintos conceptos de lo personal, lo político, y lo económico. Así, la autora especifica diferentes connotaciones del término "poder": "power over", poder controlador; "power to", poder generativo o productivo; "power with", un sentido de unidad de un grupo, mayor que la suma de sus miembros; $y$ "power from within", una fortaleza espiritual de cada uno, que permite la aceptación y el reconocimiento de los demás.

El término "empoderamiento" tiene sus orígenes en el verbo empower que aparece en Gran Bretaña a mediados del S.XVII para designar el poder o autoridad formal otorgada por un poder superior, pero no es hasta el S.XIX que se crea el término empowerment que es definido como un estado y una acción, la de dar poder (Bracqué \& Biewener, 2013). Vemos, pues, que desde sus orígenes existe una estrecha relación entre poder y empoderamiento.

Entre las distintas nociones de empoderamiento se pueden diferenciar como mínimo dos grandes enfoques, a partir del cuestionamiento o no de las estructuras existentes y del poder establecido. Un primer enfoque estaría formado por las nociones de empoderamiento vinculadas a la corriente pedagógica de la educación popular y las propuestas de Paulo Freire $(1987,1988)$. Éstas apuestan manifiestamente por la toma de conciencia que invita a revisar las estructuras y el sistema establecido. También en esta primera clasificación podemos incluir las propuestas del enfoque feminista del empoderamiento de las mujeres, el cual implica tanto un cambio individual, como la acción colectiva y la apuesta por la modificación de las estructuras que reproducen la subordinación de las mujeres como género (Sen \& Grown, 1988). Este enfoque del em- ting it, according to the discourse or analysis approach (pedagogical, psychological, sociological, economical, etc.). Some authors have deepened in this concept, and among the ones that had made it from the community psychology we have to point out works from Rappaport (1981, 1985, 1986, 1987), for whom the empowerment is the aim of the community psychology theory. At the same time, the etymology of empowerment sends us to studies of the different disciplines and approaches to the concept. According to Rowlands (1997, p.13) the empowerment concept's understanding may vary depending on the power's interpretation; where several different concepts of personal, politics, and economics are linked. In that way, the author specifies different connotations of the term "power": "power over", controlling power; "power out", generative or productive power; "power with", a unity sense of group, bigger than the sum of its parts; and "power from within", the spiritual fortress of each one, which allows the acceptance and acknowledgement of the others.

The "empowerment" term comes from the verb empower which arose in Great Britain in the middle of the XVII Century to designate the formal authority or power given by a superior figure, but it was not until the XIX Century when the empowerment concept is created and it is defined as a condition and an action: the one of giving power (Bracqué \& Biewener, 2013). So, we know that from its beginning there is a close relation between power and empowerment.

Two big approaches can be detected amongst the different empowerment ideas, starting from questioning or not the empowerment ideas of the established power. One of these approaches is based on the empowerment ideas linked to popular education and Paulo Freire's proposals $(1987,1988)$. Those proposals rely on the rising of awareness that encourage revising the established structures and system. In this first classification we can also include the proposal of the feminist approach for women empowerment, which implies both an individual change and a collective action and the claim for a structure's modification that reproduce the subordination of women as gender (Sen \& Grown, 1988). This empowerment approach suggests an increase on power, the access to the use and control of ma- 
poderamiento sugiere un incremento de poder, el acceso al uso y control de los recursos materiales y simbólicos y la participación en el cambio social. Tiene un carácter holístico o multidimensional que implica la superación de desigualdades o déficits a partir de un proceso de transformación y de superación de la opresión (Maton, 2008).

La extensión del término llega a las agencias de cooperación para el desarrollo y pasa a aplicarse a distintos colectivos vulnerables como objetivo de intervención para su desarrollo y da lugar a un segundo enfoque en el que el concepto de empoderamiento adquiere algunos matices específicos, significando un incremento de la capacidad individual para ser más autónomos y autosuficientes, depender menos de la provisión estatal de servicios o empleo y tener más espíritu emprendedor para crear microempresas y empujarse uno mismo en la escala social. Estas posiciones no cuestionan las estructuras existentes y son en la actualidad los planteamientos más extendidos a partir de los programas para el desarrollo que promueven las administraciones públicas o los grandes organismos internacionales. Desde este enfoque, empoderar implica ser emprendedor y dominar los recursos y medios que el sistema pone a nuestro alcance

Bacqué y Biewener (2013) identifican un tercer modelo o aproximación al empoderamiento, el enfoque social-liberal. Este coincide con una forma de liberalismo social que legitima al Estado y las políticas públicas para la promoción de los derechos cívicos y la reducción de las desigualdades sociales y económicas. Se persigue la defensa de las libertades individuales poniendo atención en la cohesión social y la dimensión comunitaria sin cuestionar las estructuras establecidas. El empoderamiento en este caso está relacionado con la igualdad, la oportunidad, la lucha contra la pobreza, la gobernanza y la capacitación para elegir. Según Bacqué y Biewener, es el modelo hacia el cual evolucionan la mayoría de prácticas profesionales.

Si entendemos el empoderamiento desde la perspectiva que puede llegar a cuestionar las estructuras y el sistema establecido, hay que pensar que algunas iniciativas empoderadoras no serán las más habituales en los proyectos comunitarios y socioculturales impulsados desde determinadas estructuras conservadoras (públicas o privadas). terial and symbolic resources and the participation in the social change. It has a holistic or multidimensional nature, which implies overcoming inequalities or shortfalls starting from a process of transformation and overcoming the oppression (Maton, 2008).

The term's extension arrives to development cooperation agencies and it is applied to different vulnerable groups as the aim for intervention for its development. This derives into a second approach in which the empowerment concept acquires some specific aspects, with an increase of the individual capacity to be more independent and self-sufficient, to rely less on the governmental aid or employment and to have more enterprising spirit in order to create microenterprises and to go forward in the social scale. These positions do not question the existing structures and nowadays are the more extended approaches from development programs promoting public administrations or big international organizations. From this approach, to empower implies being independent and to dominate the sources and resources that the system provide us.

Bacqué and Biewener (2013) identify the third model or approach for empowerment; the social-liberal's approach. This approach agrees in a way with the social liberalism that legitimizes the State and the public policies for civic rights' promotion and the social and economic disparities' reduction. The aim is to defend the individual freedoms paying attention to social cohesion and community aspects without questioning the established structures. In this case the empowerment is related to equity, opportunity, fight against poverty, governance, training and capacity of choosing. According to Bacqué and Biewener, it is a model towards which most professional practices develop.

If we understand the empowerment from an approach that questions the founded structures and systems, we must think that some empowerment initiatives will not be the most usual in the sociocultural and community projects encouraged by some conservative structures (public or private). To empower implies to give up power and it is always difficult to refuse to it, both in a particular and an institutional scale.

According to San Pedro (2006), the empowerment is linked to community participation, the collective decision taking, the good government, the 
Empoderar implica ceder poder y es siempre difícil renunciar a él, tanto a nivel particular como a nivel institucional.

El empoderamiento se relaciona con la participación comunitaria, la toma colectiva de decisiones, el buen gobierno, la idea de plena ciudadanía o la democracia (San Pedro, 2006). Pero también es un término que tiene que ver con las políticas neoliberales y la agenda para el desarrollo del Banco Mundial (Lutrell, Quiroz, Scrutton \& Bird, 2009) y con ellos con una determinada forma de entender el desarrollo, la participación y la democracia. La internacionalización del concepto ha provocado una tendencia a la despolitización y a reforzar su dimensión individual frente a la social y política que inicialmente tenía (Bacqué \& Biewener, 2013). Queda claro que hay enfoques y discursos con distintos alcances e implicaciones y que no se trata de un concepto simple. Es un constructo multi-nivel que consiste en enfoques prácticos y aplicativos, procesos de acción social y resultados individuales y colectivos (Jennings, Parra-Medina, Hilfinger \& McLoughlin, 2013). La complejidad del término según Tromp (2007) determina que sea imposible abordar un solo aspecto del empoderamiento ya que cada variable afecta a la siguiente. Desde esta consideración de complejidad apostamos por una idea de empoderamiento vinculada a un proceso de crecimiento, fortalecimiento, habilitación y desarrollo de la confianza de los individuos y las comunidades para impulsar cambios positivos en el contexto, ganar poder, autoridad, capacidad de decisión y cambio tanto individualmente como de forma colectiva (Adamson \& Bromiley, 2008; Alsop, Frost \& Holland, 2006; Titterton \& Smart, 2008). Todo ello implica la autorrealización y emancipación de los individuos y comunidades, el reconocimiento de los grupos/comunidades y la transformación social.

La distinción entre el empoderamiento individual y el empoderamiento comunitario es básica, aunque en la práctica están estrechamente relacionados en la medida que la mayor parte de los programas existentes no entienden el progreso de uno sin el otro. Como argumenta Maton (2008), un escenario empoderador tiene el potencial para contribuir en tres ejes: el individual, el comunitario y el que incide en la sociedad en general, para reducir la marginalización y recuperar los derechos de personas y grupos. full citizenship idea or the democracy. It is also a term that has to do with neoliberal politics and the World Bank's development agenda (Lutrell, Qiuroz, Scrutton \& Bird, 2009) along with a specific way of development, participation and democracy understanding. The internationalization of the concept has derived into an inclination to depoliticization and to reinforce its individual scale versus the initial social and politic scale (Bacqué \& Biewener, 2013). It is clear that there are approaches and discourses with different scopes and implications and that it is not an easy concept. It is a multi-scale construct made of practical and applicative approaches, social action processes and individual and collective results (Jennings, Parra-Medina, Hilfinger \& McLoughlin, 2013). According to Tromp (2007) the term's complexity establishes that it is impossible to address just one aspect of empowerment because each variable concerns the following one. From this complex view, we rely on an empowerment idea linked to a process of growth, strengthening, capacitation and development of trust of individual and communities to boost positive changes in the context; gain power, authority, decision taking ability and changes in an individual and collective scale (Adamson \& Bromiley, 2008; Alsop, Frost \& Holland, 2006; Titterton \& Smart, 2008). All this implies the self-fulfilment and emancipation of individuals and communities, the recognition of communities/groups and the social transformation.

The distinction between individual and community empowerment is essential, although in practice they are closely related as the majority of the existing programmes do not understand one progress without the other. According to Maton (2008), an empower scene has potential to contribute in three axes: the individual, the community and the one that influences the society in general, in order to reduce the marginalization and to retrieve the rights for persons and groups. In 1997 Sadan said that the connection between individuals and community is clear, suggesting a contextual-ecological approach to deal with social situations. The action with the group, collective or community is the most important source for learning, progress and personal transformation. The community turns into a powerful educational agent becoming essential for individual empowerment. Of course, the community empowerment re-

[ 54 ] PERE SOLER, ANNA PLANAS, ANNA CIRASO-CALÍ Y ARANTXA RIBOT-HORAS 
Sadan (1997) considera evidente la conexión entre los individuos y la comunidad, sugiere una aproximación contextual-ecológica para el tratamiento de situaciones sociales. La acción con el grupo, el colectivo o la comunidad es la principal fuente de aprendizaje, progreso y transformación en cada sujeto. La comunidad se convierte en un potente agente educativo y llega a ser fundamental para el empoderamiento individual. Por supuesto, el empoderamiento comunitario requiere del empoderamiento individual para ser una realidad sólida. Según San Pedro (2006) el empoderamiento individual avanza en la medida que el sujeto toma conciencia de sus posibilidades a la vez que puede contribuir de forma más activa a la acción colectiva. El empoderamiento individual amplifica la voz colectiva. Exige respeto al otro a la vez que el otro aumenta en el respeto a sí mismo (Vidal, 2009). Requiere esta dimensión social a la vez que implica una evidente concreción individual en la medida que significa hacerse efectivamente responsable de la propia vida. También Pick, Sirkin, Ortega, Osorio, Xocolotzin y Givaudan (2007) defienden que el concepto de empoderamiento tiene sentido en la medida que la agencia personal empieza a impactar en la comunidad.

\subsection{Indicadores de empoderamiento}

El empoderamiento ha sido definido también como uno de los cinco ejes de la acción comunitaria, junto con la participación, la concienciación, la educación y el desarrollo (Varela Crespo, 2010). No obstante, no existe un método aceptado para su medición, y el seguimiento de los cambios que con él se producen (Mosedale, 2003). Se ha avanzado en la dirección de delimitar algunos dominios o variables que constituyen el empoderamiento y se han formulado propuestas de evaluación en este sentido (Bowers, 2004; Forde \& Theobald, 2006; Holte-McKenzie, Plottu \& Plottu, 2009; INTRAC, 1999; Paxton, Valois \& Drane, 2005; Rutherford \& Lewis, 1997). Hay también aportaciones desde el contexto español (DíazPuente et al., 2008; Díaz-Puente, Cazorla \& De los Ríos, 2009). Con ellas se busca hacer evidente, y por tanto valorable, el progreso personal y colectivo conseguido con determinadas acciones y programas.

Los atributos que significan empoderamiento en un contexto pueden tener diferente significado en quires the individual empowerment in order to be a solid reality. According to San Pedro (2006) the individual empowerment moves forward so the subject is aware of his own capacities while contributing more actively in the collective action. The individual empowerment enlarges the collective voice. It demands respect for the other at the same time that the other increases its own respect (Vidal, 2009). This social scale is required and, at the same time, implies a clear individual concretion to the extent that it means being responsible of its own life. Pick, Sirkin, Ortega, Xocolotin and Givaudan (2007) explained empowerment term makes sense in the extent that personal agency starts to have an impact in the community.

\subsection{Empowerment indicators}

Varela Crespo (2010) defined empowerment as one of the five axes for community action along with participation, consciousness-raising, education and development. Nevertheless, according to Mosedale (2013), we do not have an accepted method for the measuring and monitoring of the changes that it produces. Improvements have been made towards marking out some areas or variables that constitute empowerment and evaluation proposals had also been (Bowers, 2004; Forde \& Theobald, 2006; Holte-McKenzie, Plottu \& Plottu, 2009; INTRAC, 1999; Paxton, Valois \& Drane, 2005; Rutherford \& Lewis, 1997). There are also some contributions in the Spanish side (Díaz-Puente et al., 2008; DíazPuente, Cazorla \& De los Ríos, 2009). Which aim is to make evident, and therefore valuable, the personal and collective progress reached by specific actions and programs.

The meaning of empowerment in a given context can have a different one in other context. Moreo- 
otras realidades. Además, la medida que se pueda desarrollar en un estudio puede que no sea la apropiada para otro. Estas han de ser culturalmente apropiadas para medir el incremento de poder de los miembros de la comunidad (Hombrados-Mendieta \& Gómez-Jacinto, 2001). Aun así, contribuir a esta visibilidad es, seguramente, el mayor argumento a favor de reconocer y dar valor a determinadas propuestas educativas y acciones comunitarias. Quizás la medición universal del empoderamiento es imposible, pero investigaciones comparativas revelan que algunos indicadores de empoderamiento son más universales que otros (Malhotra, Shuler \& Boender, 2002) y, en cualquier caso, desvelar los límites y efectos de determinadas prácticas educativas solo puede comportar un mayor conocimiento.

En este sentido se han formulado algunas propuestas de indicadores específicos para valorar el empoderamiento. Entre ellas encontramos las aportaciones de Laverack (2001, 2005) el cual distingue nueve dominios a tener en cuenta para construir empoderamiento y capacidad en las comunidades: (1) mejorar la participación, (2) desarrollar liderazgo local, (3) incrementar la capacidad de evaluación de problemas, (4) fomentar la habilidad de "preguntar por qué", (5) construir estructuras de empoderamiento organizacional, (6) aumentar la movilización de recursos, (7) fortalecer enlaces con otras organizaciones y personas, (8) crear una relación equitativa con agentes externos y (9) aumentar el control sobre la gestión de programas. Pick et al. (2007) también formulan una propuesta de escala para medir el empoderamiento, relacionando este concepto con el de agencia personal, a través de la ESAGE (Escala de Agencia Personal y Empoderamiento). Tiene en cuenta las siguientes variables: autoeficacia, autodeterminación, control sobre las propias conductas, pensamiento independiente, identificación de necesidad de cambio, miedo al éxito, reconocimiento del propio aprendizaje, percepción del propio contexto y control sobre el propio entorno. Su propuesta se presenta como adecuada para el impacto conjunto producido por la agencia personal y el empoderamiento.

Los indicadores para evaluar cambios en el empoderamiento de Holt-McKenzie, Forde y Theobald (2006) merecen también ser destacados. Esta aportación se realizó a través de un proceso de EP con chicas participantes en un proyecto de la ONG Mo- ver, as long it can be developed in a study, it may not be suitable for other context. Those must be culturally appropriate in order to measure the power increase of the community members (HombradosMendieta \& Gómez-Jacinto, 2001). Even though, to contribute to its visibility is the biggest argument in favour of giving recognition and value some educational proposals and community actions. The empowerment's universal measurement may be impossible, but comparative researches revealed that some empowerment indicators are more universal than others (Malhotra, Shuler \& Boender, 2002), and, in any case, to uncover limits and effects that some educational practices can just imply to gain a bigger knowledge.

In this sense, some proposals for specific indicators to value empowerment had been made. Among them, some from Laverack $(2001,2005)$ where nine areas must be taken into account in order to build the empowerment and the community abilities: (1) improve the participation, (2) local leadership development, (3) increase the capacity for problems evaluation, (4) encourage the ability of "asking why", (5) to build organizational empowerment structures, (6) increase the source mobilization, (7) strengthen links with other organizations or persons, (8) to create a fair relation with outside agents and (9) to increase the control over programme management. Pick et al. (2007) also made a proposal for measuring the empowerment, linking this concept with the one of personal agency through ESAGE (Scale for Measurement of Personal Agency and Empowerment). It relies on those variables: -efficiency, self-determination, control over one's own behaviour, independent thinking, identify the change necessity, fear to success, own learning awareness, self context perception and control over one's own environment. This proposal was considered accurate for the global impact produced by the personal agency and empowerment.

The indicators to evaluate the empowerment's changes of Holt-McKenzie, Forde and Theobald (2006) should be pointed. This contribution was made from a PE process with girls participating in a NGO project called Moving the Goalposts Kilifi, and defines 13 indicators gathered into 5 variables (called abilities for life): team work (discipline, team work to solve problems, having common objectives), 
ving the Goalposts Kilifi, y define 13 indicadores agrupados en 5 variables (llamadas habilidades para la vida): trabajo en equipo (disciplina, trabajar juntos para resolver problemas, tener objetivos comunes), liderazgo (comportamiento, respecto por uno mismo, ayudar a la gente), organización (llevar planes a término, negociar con los padres sobre las tareas), confianza (coraje, no ser tímido, creer en una mismo), y autoestima (sentirse bien con uno mismo y sentir que uno está bien aunque los otros digan lo contrario). Cada indicador se define y se concreta en sub-indicadores.

Conocer y utilizar la aproximación a estos dominios puede permitir ganar comprensión sobre las áreas de influencia y transformación de la vida de estas comunidades (Fetterman \& Wandersman, 2007) y nos puede ser útil para orientar mejor y conocer el potencial transformador de muchos de los programas y acciones socioeducativas. Este es justamente el problema general que la presente investigación aborda.

La aportación que aquí se presenta parte del presupuesto que una mayor certeza sobre las prácticas y procesos educativos empoderadores mejoraría los resultados de las intervenciones socieducativas y el trabajo comunitario. Se trata de aportar conocimiento y herramientas que nos permitan avanzar con mayor seguridad en los procesos de acción socioeducativa. La investigación se delimita en los aprendizajes obtenidos a través de procesos de EP y pretende averiguar en qué medida estos aprendizajes contribuyen al empoderamiento de las personas y comunidades que protagonizan dicha evaluación.

El objetivo de este material es proporcionar nuevas herramientas en el ámbito del empoderamiento individual y comunitario. La aportación en este caso se concreta en un primer sistema de indicadores de empoderamiento individual y comunitario que nos permita evidenciar y concretar cómo podemos detectar o percibir si nuestras acciones y proyectos favorecen el empoderamiento.

\section{Método: Construcción de un sistema de variables e indicadores de empoderamiento}

En la figura 1, ilustramos gráficamente el proceso realizado para confeccionar el sistema de variables e indicadores de empoderamiento que aquí se pre- leadership (behaviour, respect for oneself, help people), organization (take plans to an end, negotiate task with parents), trust (bravery, not being shy, believe in oneself) and self- esteem (felling good with oneself and felling good even if the others said we are not). Every indicator is defined and determined with sub-indicators.

Knowing and using the approximation to those fields can make us gain understanding over the influence and transformation areas of these community lives (Fletterman \& Wandrsman, 2007) and can help us to have a better orientation and to see the transformation potential of many socio-educational actions and programmes. This is exactly the general problem addressed in this research.

The contribution shown in this paper starts from the estimation that a bigger certainty over empowering educational practices and processes will improve socio-educational intervention results and the community work. It is about providing knowledge and tools that drives us forward with a higher sureness in socio-educational action processes. The research is limited by the knowledge obtained through PE processes and tries to discover how this knowledge contributes the empowerment of people and communities responsible for that evaluation.

The aim of this material is to provide with new tools in the individual and community empowerment sphere. The contribution turns real in a first individual and community empowerment indicators system that helps us to demonstrate and certify how can we detect or notice if the empowerment is boosted by our actions and projects.

\section{Method: Construction of a system of em- powerment variables and indicators}

In figure 1, we illustrate the processes carried out with a chart to prepare the system of empowerment variables and indicators hereby presented. It is a 3- 
Figura 1. El proceso de confección del sistema de variables e indicadores de empoderamiento

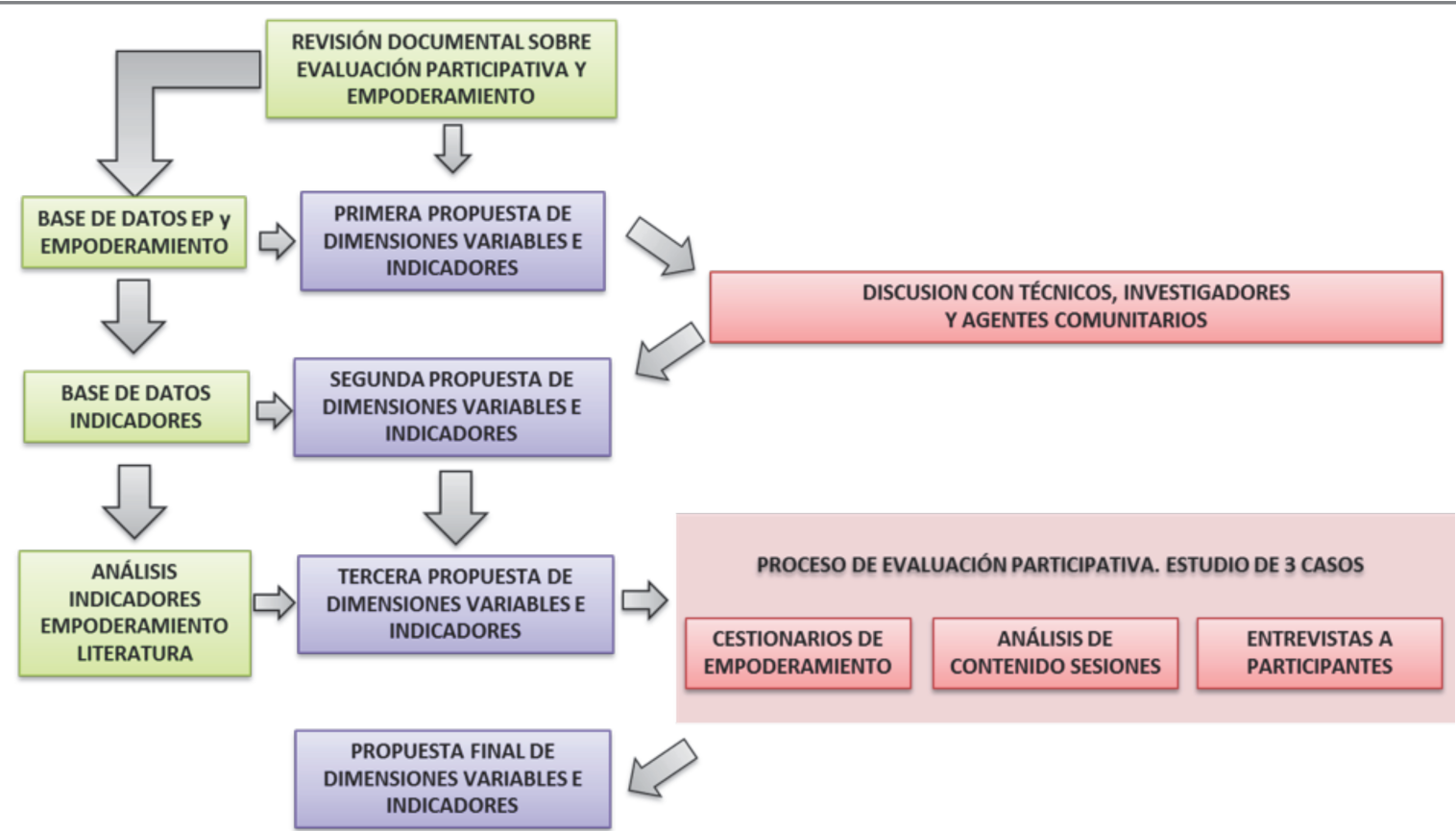

Fuente: elaboración propia.

Figure 1. The creation of a system of empowerment variables and indicators

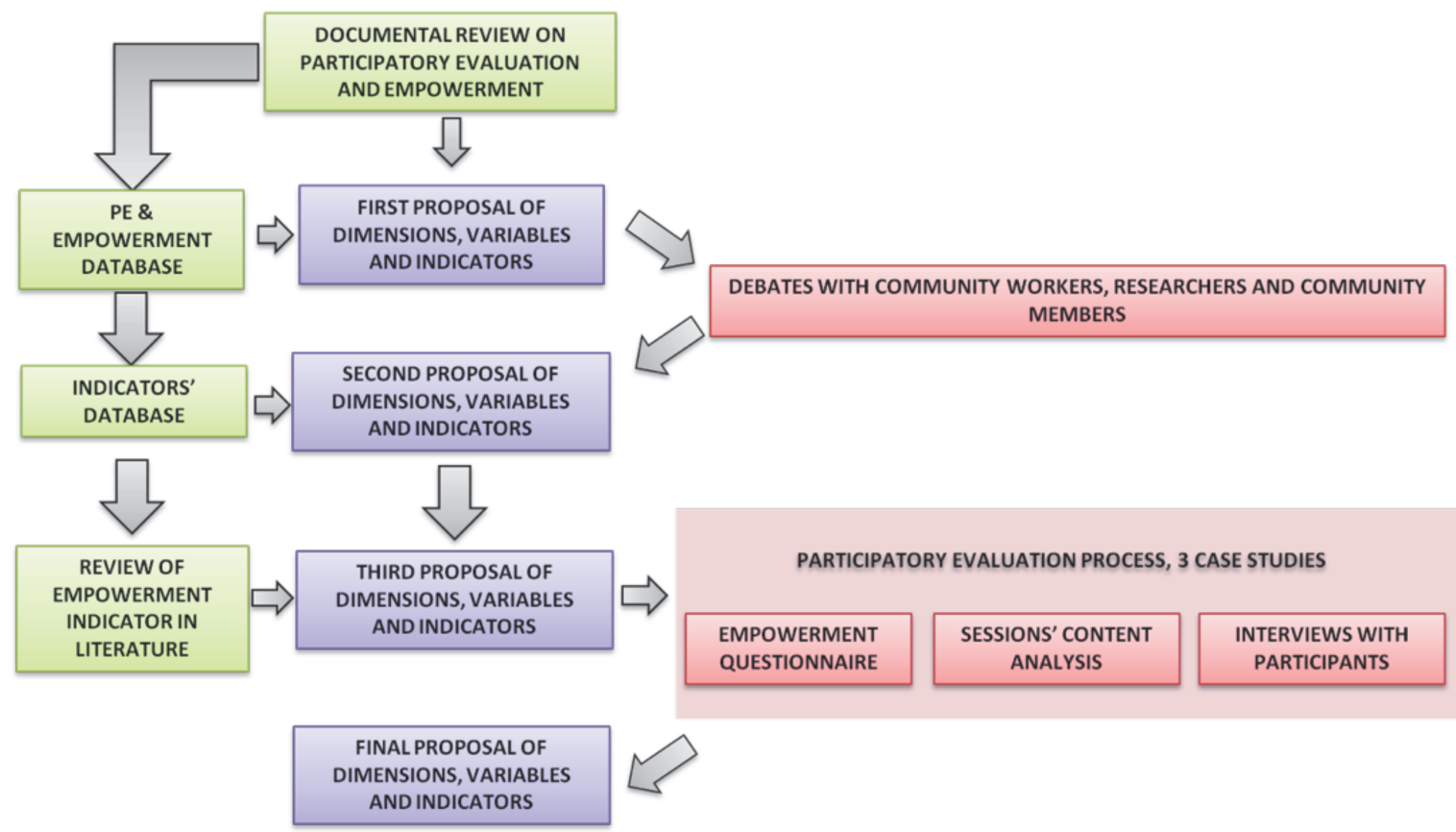

Source: authors.

senta. Se trata de un proceso de más de tres años en los que se configura, revisa y reformula hasta cuatro versiones distintas del sistema. Se parte de la revisión documental sobre EP y empoderamiento, con la finalidad de disponer de un estado del arte sobre la temática y configurar una base de datos propia. A partir de esta documentación, se esboza un primer sistema de variables e indicadores que forman parte

year process in which up to four versions of the system were created, revised and reformulated. It begins with a documental revision about PE and empowerment, with the goal of having a state of art on the subject and to configure its own database. From this documents, it is outlined the first system of variables and indicators as a part of the discourse and experiences detected on PE and empowerment. 
del discurso y las experiencias detectadas sobre EP y empoderamiento. Este primer sistema de variables e indicadores es sometido a discusión y validación a través de expertos procedentes del ámbito técnico, universitario y del trabajo comunitario. El resultado es un nuevo sistema más claro, reducido y contrastado con la práctica profesional.

Paralelamente, se realiza un proceso de listado de todos los indicadores de empoderamiento que podían detectarse en nuestra base de datos bibliográfica. Se detecta que de los artículos que abordan directamente nuestra temática, aproximadamente la mitad proporcionan indicadores. Se transcriben, ordenan y se contrastan con nuestra primera propuesta. Este proceso introduce mejoras y ajustes en nuestro sistema y permite argumentar $y$ fundamentar mejor algunas de las propuestas. Todo ello da lugar a la tercera propuesta que es contrastada a través de tres estudios de caso en tres procesos de EP de planes comunitarios. Este proceso se prolonga más de un año con las distintas comunidades y permite ensayar y mejorar sustancialmente la propuesta final de variables e indicadores.

En los apartados siguientes presentaremos con más detalle los procesos e instrumentos utilizados y someteremos a discusión y reflexión los resultados obtenidos.

\subsection{Fundamentación teórica y diseño de la primera propuesta de indicadores de empoderamiento}

La fase de fundamentación teórica de la investigación realizada incluye tres procesos que permiten configurar el sistema de indicadores de empoderamiento, que posteriormente será sometido al estudio en tres casos prácticos. Los procesos son: revisión de la literatura más relevante en torno a procesos de EP y de empoderamiento; discusión y debate con técnicos y agentes comunitarios; y análisis de los indicadores de empoderamiento que se explicitan o deducen de la documentación revisada.

2.1.1. Revisión documental y formulación de la primera propuesta de indicadores

Se realiza, en primer lugar, una revisión documental de artículos científicos, publicados entre los años 2000 y 2010 , con las siguientes palabras clave: em-
This first system of variables and indicators is debated and validated by community workers and university researchers. The result is a new system more clear, reduced and contrasted with the professional practice.

At the same time, a list with all the empowerment indicators that can be detected in our bibliographic database is created. It is detected that half of the papers dealing with our subject provide with indicators. They are transcribed, organized and contrasted with our first proposal. During this process some improvements and adjusts are made in our system, and that helps us to argument and give a better support to some proposals. All that leads to a third proposal checked through three case studies on three PE processes of community plans. This process goes over a year in several communities and allows us to train and improve the final version of variables and indicators.

In the following sections we will present more precisely the processes and tools used and we will submit the obtained results to debate and deliberation.

\subsection{Theoretically foundation and design of the first empowerment indicators' proposal.}

The theoretical-based phase of the research includes three processes that help to create an empowerment indicators' system, which will later on be studied in three practical cases. Those processes are: more relevant literature revision on PE processes and empowerment; discussion and debate with community workers; and analysis of the empowerment indicators that are deduced from the literature.

2.1.1 Documental revision and formulation of the first indicators' proposal

In the first place, we made a documental revision on the scientific papers published over the years 2000 and 2010 containing the following key: empower- 
powerment, participatory evaluation, participatory assessment, empowerment evaluation, empowerment indicators, community evaluation, junto con los descriptores: proyecto, práctica, experiencia y teoría, según el contenido de los artículos. A través de esta revisión, se obtienen 112 documentos de los cuales se seleccionaron 58 por ajustarse a los criterios establecidos por el equipo de investigación: el marco temporal, los descriptores, la tipología de documentos, la concreción de los objetivos, procedimientos y finalidades de los documentos (se puede consultar el proceso completo de revisión en Gil, Heras \& Llena, 2013).

Los artículos obtenidos son revisados, clasificados y ordenados según el tratamiento de nuestro objetivo de estudio. Esta labor permite documentarnos sobre el estado del arte, detectar los principales aspectos de discusión y situar el punto de partida de nuestra propuesta de indicadores. Se formula, así, un primer listado inicial de variables e indicadores de empoderamiento con 18 variables agrupadas en cinco bloques: dos referidas al empoderamiento individual (interpersonales e intrapersonales) y tres referidas al empoderamiento comunitario (identidad, capacidad organizativa y acción comunitaria). En total, se concretan 50 indicadores de empoderamiento que desarrollan y especifican las variables definidas.

\subsubsection{Discusión y debate con técnicos,}

investigadores y agentes comunitarios

La primera clasificación de variables e indicadores de empoderamiento es sometida a discusión en una sesión de trabajo de 20 personas: diez investigadores y diez técnicos y participantes en procesos de dinamización comunitaria. El objetivo de la sesión es concretar cinco variables de empoderamiento en indicadores, evidencias e instrumentos que permitan obtener medidas objetivas de empoderamiento entre el principio y el final de la EP. La sesión inició con una breve presentación de la clasificación de variables por parte del equipo de investigación. Después de una ronda inicial de dudas, se seleccionaron las 5 variables consideradas clave para el empoderamiento (libertad, reconocimiento, conocimiento comunitario, responsabilidad comunitaria y capacidad de evaluación) y posteriormente se distribuyeron ment, participatory evaluation, participatory assessment, empowerment evaluation, empowerment indicators, community evaluation, along with the descriptors: project, practice, experience and theory, according to the papers content. Through this revision, 112 documents were obtained from which 58 were selected to be closer to the research team criteria: temporal frame, descriptors, document typology, objects concretion, procedures and documents aim (the full revision process can be checked at Gil, Heras \& Llena, 2013).

The obtained articles are revised, classified and organized according to how they treat our study object. This action allows us to familiarise with the state of art, to detect the debate around main aspects and to locate the starting point of our indicators' proposal. So, a first initial list of empowerment variables and indicators is made with 18 variables in 5 blocks: two of them referring to individual empowerment (interpersonal and intrapersonal) and three referring to community empowerment (identity, organizational capacity and community action). Overall, 50 empowerment indicators developing and specifying the defined variables are fixed.

2.1.2 Discussion and debate with technicians, researchers and community agents

The first empowerment variables and indicators' classification is discussed by 20 people in a work session: ten researchers and ten technicians and participants in community development and sociocultural animation processes. The aim of the session is to provide five empowerment variables with indicators, evidences and tools that help to obtain objective empowerment measures between the beginning and the end of the PE. The session began with a short presentation of the variables classification made by the research team. After an initial doubts round, the 5 key variables for empowerment were selected (freedom, acknowledgment, community knowledge, community responsibility and evaluation capacity) and after that the 20 participants were distributed in 4 sub-groups, which wor- 
las 20 personas asistentes en 4 subgrupos, que trabajaron durante dos horas la concreción de estas variables. La puesta en común del trabajo de estos subgrupos permitió aclarar terminología, esbozar unas primeras definiciones de las variables analizadas y consensuar estrategias y dimensiones a tener en cuenta para realizar la primera versión del sistema de variables e indicadores. Posteriormente, los investigadores del proyecto se distribuyeron el resto de variables para realizar la misma tarea y especificar indicadores, evidencias e instrumentos en cada variable.

La construcción de una clasificación propia de indicadores nos invita a concretar la evaluación del empoderamiento a partir de diferentes niveles. Un primer nivel son las variables a evaluar para referirnos al aspecto o tema que se quiere valorar. Cada variable puede concretarse en uno o más indicadores que permitirán centrar y delimitar los elementos de valoración en la variable. El segundo nivel equivale a los indicadores de evaluación propiamente dichos, que a su vez se concretan y explican a través de las evidencias que permiten aplicar y obtener información de cada uno de los indicadores y con ello comprobar si el indicador se da o no en cada caso. El resultado de esta clasificación es un primer listado con 23 variables: 13 relativas a la evaluación del empoderamiento individual y 10 más relativas al empoderamiento comunitario.

Por ejemplo, dentro de la variable de organización de la comunidad, el indicador de "circulación fluida de información en la comunidad" se concreta en las siguientes evidencias:

- Existencia y diversidad de fuentes, canales y redes de información en uso (boletines, revistas, redes sociales, blog, etc.);

- Actualidad en la información distribuida;

- Inmediatez de la difusión de la información;

- Coordinación entre los canales y redes de información.

Estos aspectos se pueden recoger mediante valoraciones de miembros de la comunidad que pueden expresar su percepción acerca del nivel de fluidez de la información o analizando directamente los canales informativos existentes. ked during two hours to set those variables. Putting these sub-groups work into common helped to clarify terminology, to outline the first definitions of the analysed variables and to agree over strategies and dimension required in order to create a first version of the variables and indicators system. Later on, the project researchers distributed the rest of variables to do the same task and to specify indicators, evidences and tools for each variable.

The creation of our own classification for indicators leads us to set the empowerment evaluation from different levels. The first level is the variable to assess, which is the aspect or subject that is going to be assessed. Each variable can be set on one or more indicators, which will help to center and limit the variable's assessment components. The second level is made for the evaluation indicators strictly speaking, which in turn will be set and explained through evidences that help to apply and collect information of each indicator and, in that way, checking if it appears or not in each case. As a result of this classification a first list of 23 variables is obtained: 13 of individual empowerment and 10 of community empowerment.

For instance, in the community organization's variable, the following evidences set the variable "fluid information flow in the community":

- Existence and diversity of sources, channels and information networks in use (newsletters, magazines, social networks, blog, etc.);

- Updated distributed information;

- Information closeness distribution;

- Coordination between information channels and networks.

These aspects can be collected through the assessment of community members that can perceive the level of information fluidity, or directly by analyzing the already existent information channels. 
2.1.3. Segunda revisión bibliográfica de indicadores de empoderamiento

Paralelamente al trabajo con los técnicos comunitarios y vecinos se trabaja en la revisión documental de los 58 documentos seleccionados. Estos materiales se registran en una base de datos electrónica configurada con 38 campos, con la finalidad de clasificar y ordenar toda la información sobre indicadores de empoderamiento. En esta base de datos se registran los indicadores que se detectan en 30 de los 58 documentos analizados. Los principales campos que se consideran en la base de datos son:

- Nombre del indicador o variable que se propone en el artículo;

- Tipología de indicador o variable (individual o comunitario);

- Descripción o definición del indicador o variable;

- Referencia del documento donde se detecta el indicador;

- Tipología de documento donde se detecta el indicador

- Título breve que describa el proyecto o la experiencia;

- Metodología por la cual se obtienen las evidencias del indicador;

- Instrumentos utilizados para evidenciar el indicador;

- Descripción de límites o dificultades;

- Observaciones.

Se detectan pocas aportaciones que tengan como finalidad el planteamiento o el estudio explícito de indicadores de empoderamiento. Únicamente en 22 documentos de los 58 existentes se identifican indicadores concretos. A través de estos artículos se obtiene un total de 60 registros que se analizan y se vinculan al listado de indicadores creado durante el proceso de investigación del equipo. El proceso de análisis consiste en una revisión en profundidad de cada texto, la detección de los términos que identifican cada indicador o de los términos que definen dichos indicadores. En cada caso, el proceso de análisis previo es sometido a discusión con todo el equipo de investigación. Se construye así un listado con 45 indicadores de empoderamiento, 22 de los cuales -prácticamente la mitadson contrastados por diferentes referencias de la
2.1.3 Second empowerment indicator's bibliographic revision

While the researchers are working with the community workers and neighbors, a bibliographic review of the 58 selected documents is made. Those materials are recorded in the 38 fields of an electronic database, with the aim of classifying and organizing all empowerment indicators' information. The database contains the indicators detected in 30 of those documents. The database main fields are:

- Name of the indicator or variable proposed in the paper;

- Typology of indicator or variable (individual or community);

- Description or definition of the indicator or variable;

- Mention of the document where the indicator is detected;

- Type of document where the indicator is detected;

- Short title describing the project or experience;

- Method used to obtain indicator's evidence;

- Tools needed to evidence the indicator;

- Limits or difficulties description;

- Researchers' remarks.

There are little contributions that specifically study empowerment indicators. Only 22 out of 58 documents identify precise indicators. Through these papers 60 registries are obtained, analyzed and linked to the list of indicators built during the team research process. The analysis process consists on a deep revision of each text, and the detection of terms that identify or define each indicator. In each case, the research team discusses the previous analysis process. A list of 45 empowerment indicators is built, 22 of them -almost halfare several times contrasted in the analyzed biography. The rest must be contrasted from observation and tested in PE processes. That is the next step. 
bibliografía analizada. El resto de indicadores han de contrastarse a partir de la observación y el ensayo en procesos de EP. Éste es el siguiente paso.

\subsection{Estudio de casos del empoderamiento en procesos de EP de tres planes comunitarios}

Para el contraste, revisión y reformulación de los indicadores de empoderamiento se aplican diferentes instrumentos y estrategias que aportan evidencias de los aprendizajes producidos durante el proceso de EP. El contraste de los aprendizajes identificados, una vez finalizados los procesos de EP en cada comunidad, es lo que nos permite ver en

\subsection{Empowerment case studies in PE process of three community plans}

Different tools and strategies contributing with evidences from the learning obtained during the PE process are applied in order to do the contrast, revision and reformulation of the empowerment indicators. The contrast of the identified learning, once the PE in each community ended, is what helps us to see how our indicators react to the detected evidences.

The three community plans selected to develop the PE are located in Catalonia; each one is founded in a case, according to Coller (2002). The PE

Tabla 1. Síntesis de instrumentos utilizados en los estudios de caso

\begin{tabular}{ll}
\hline Técnica/instrumento & Procedimiento \\
\hline Cuestionario inicial & Cuestionario inicial compuesto de 31 ítems. Se aplica a 30 participantes en el proceso de EP entre las \\
& comunidades que configuran los tres casos de estudio. \\
& Se complementa la muestra de estudio con 19 cuestionarios a vecinos de las tres comunidades, ajenos \\
& al proceso de EP. Este grupo se constituirá como grupo control.
\end{tabular}

\begin{abstract}
Actas y Se redactan 36 actas a partir de las reuniones realizadas en los tres estudios de caso. Este material transcripciones configura la materia prima objeto del análisis de contenido, a partir de las variables e indicadores de empoderamiento.
\end{abstract}

Cuestionario final Se vuelve a pasar el cuestionario inicial al grupo de EP que constituyó la muestra inicial. El cuestionario en esta ocasión incorpora, para los participantes de la EP, 2 preguntas abiertas sobre la valoración y experiencia de este proceso.

Se repite el cuestionario inicial al grupo control.

Entrevistas

Se realizan 11 entrevistas semi-estructuradas a 14 participantes procedentes de los tres estudios de caso.

Fuente: elaboración propia.

Table 1. Used tools summary in the case studies

\begin{tabular}{ll}
\hline Technique/toll & Procedure \\
\hline Initial questionnaire & $\begin{array}{l}\text { Initial questionnaire made of } 31 \text { items. Applied over 20 PE project's participants among the communi- } \\
\text { ties of the } 3 \text { study cases. }\end{array}$
\end{tabular}
ties of the 3 study cases.

The sample is augmented by 19 questionnaires of the three communities neighbours, external to the PE process. This group will be found as control group.

\footnotetext{
Minutes and transcripts 36 minutes come from the meetings in the three study cases. This is the raw material for content analysis, from empowerment variables and indicators.
Final questionnaire The initial questionnaire of the PE group is applied again. This time has 2 open questions to the PE par- ticipants regarding the evaluation and experience in this process.
The initial questionnaire is applied again over the control group.

Interviews 11 semi-structured interviews performed to 14 participants of the three case studies.

Source: authors.

EMPODERAMIENTO EN LA COMUNIDAD. EL DISEÑO DE UN SISTEMA ABIERTO DE INDICADORES A PARTIR DE PROCESOS DE EVALUACIÓN... [ 63 ] SIPS - PEDAGOGIA SOCIAL. REVISTA INTERUNIVERSITARIA [1139-1723 (2014) 24, 49-77] TERCERA ÉPOCA 
qué medida nuestros indicadores responden a las evidencias detectadas.

Los tres planes comunitarios seleccionados para realizar la EP se sitúan en la comunidad autónoma de Cataluña; cada uno de estos planes se constituye en un caso, siguiendo la tipología de Coller (2000). El proceso de EP se lleva a cabo durante todo el año 2012 en las tres comunidades.

La metodología de trabajo para recopilar y analizar la información dentro de cada estudio de caso es cualitativa y cuantitativa. Los instrumentos y técnicas que se aplican son un cuestionario creado adhoc; el análisis de contenido de las actas y transcripciones de las reuniones comunitarias; $y$ entrevistas semi-estructuradas (ver Tabla 1).

\subsubsection{El cuestionario de empoderamiento}

Se elaboran y aplican dos cuestionarios creados adhoc para detectar si se han realizado aprendizajes: un cuestionario al principio del proceso y otro justo al finalizar. En función de las características de los participantes de cada comunidad el formato de aplicación de los cuestionarios difiere, aplicándose en formato electrónico o en formato papel.

Los cuestionarios se aplican al grupo de participantes en la evaluación de las diferentes comunidades y a un grupo control en cada comunidad. Se obtienen un total de 49 cuestionarios iniciales, y 28 cuestionarios finales.

Ambos cuestionarios están estructurados en dos apartados. El primero incluye 18 afirmaciones relativas a los 9 indicadores de empoderamiento que se consideran más adecuados para ser analizados mediante este instrumento (iniciativa, tener un criterio propio, capacidad de establecerse normas para funcionar, conocimiento del número de servicios, recursos y equipamientos de la comunidad, discrepancia entre las percepciones de conocimiento y la situación y realidad de la comunidad, autopercepción del grado de conocimiento de la comunidad, capacidad de organización y planificación comunitaria, capacidad de decisión comunitaria y capacidad de actuar comunitariamente), que deben valorarse en una escala Likert de 1 a 4 (donde 1 es poco de acuerdo y 4 muy de acuerdo). El segundo apartado plantea 13 aspectos de conocimiento del Plan de Desarrollo Comunitario que deben ser va- process is undergone along 2012 in the three communities.

The working method to gather and analyze the information in every study case is qualitative and quantitative. The tools and techniques applied are an ad-hoc questionnaire, the act content analysis of community meetings' transcriptions; and semi-structured interviews (see Table 1)

\subsubsection{Empowerment questionnaire}

Two ad-hoc questionnaires are elaborated and applied in order to detect if learning have been obtained: one questionnaire at the beginning of the process and other at the end. According to the characteristics of the participants in each community, the application format changes, whether in electronic or paper format.

The questionnaires have two sections. The first one includes 18 statements linked with the 9 more appropriate indicators to be analyzed with this toll empowerment indicators (initiative; having own criteria; capacity to create rules to work knowledge of number of community services, equipment and resources; disagreement between perceived knowledge and the reality of the community; self-perception of community knowledge; community organization and planning capacity; community decision capacity; and community acting capacity), that should be assessed with Likert scales from 1 to 4 ( 1 means strongly disagree and 4 strongly agree). The second section contemplates 13 aspects of the knowledge of the Community Development Plan, which must be assessed by the respondents in a scale 1 to 10. Both sections have open questions so the respondents can make comments or remarks.

The final questionnaire has two open questions for the participant involved in the process; one to assess the PE process (positive and negative aspects) and other to see the meaning of participating on such a process for the respondents. 
lorados por los encuestados en una escala de 1 a 10. En ambos se incluyen preguntas abiertas para que los encuestados puedan realizar comentarios u observaciones.

En el cuestionario final se incluye, para los participantes en el proceso, dos preguntas abiertas: una para valorar el proceso de EP (aspectos positivos y negativos) y la otra para ver el significado que ha tenido para el encuestado participar en un proceso de este tipo.

Los datos cuantitativos se analizan mediante el programa SPSS. En primer lugar se comprobó la fiabilidad mediante el coeficiente Alpha de Cronbach, resultado $\alpha>.9$ en ambos cuestionarios; y coeficientes aceptables para todas las variables, siguiendo los criterios de Nunnally (1978) y Guilford (1954). Posteriormente se realizan análisis descriptivos (por territorios y conjuntamente) y comparación de medias y muestras ( $T$ de Student, prueba de Wilcoxon-signed ranks test, $U$ de Mann-Whitney). Paralelamente, se analizan los datos cualitativos categorizando las aportaciones según las variables e indicadores del listado en elaboración.

Aunque la aplicación de los cuestionarios no ha conllevado modificaciones substanciales a la propuesta de indicadores y variables, sí que ha sido útil para corroborar la idea que en estos procesos se ha generado aprendizaje. En primer lugar, el conocimiento comunitario de los participantes en la EP se mantiene estable a lo largo del proceso, mientras que en el grupo de control esta variable obtiene valores inferiores en el cuestionario final $(M=3,16$, $S D=0,5)$ respecto al cuestionario inicial $(M=3,36$, $\mathrm{SD}=0,37) ; \mathrm{t}(8)=2,5, p=0,04$. En segundo lugar, las personas que se han implicado en el proceso de EP manifiestan conocer mejor la participación comunitaria después de haber finalizado el proceso $(M=8,2$, $S D=1,42) ; t(14)=-2,58, p=0,02$, respecto a lo que conocían antes $(M=7,47, S D=1,73)$. Finalmente, se dan diferencias significativas en la valoración global del PDC que los participantes realizan en el cuestionario final. Aunque inicialmente las personas participantes en la EP y las del grupo control realizan una valoración parecida, finalmente, las personas que han estado implicadas muestran una valoración significativamente mayor respecto a la de las personas que no han participado $(U=38, p=0,27)$. Esto sugiere que el hecho de colaborar en la evaluación
Quantitative data are analyzed with SPSS program. Reliability was tested with the Cronbach alpha coefficient, resulting > .9 in both questionnaires; and acceptable coefficients for all variables according to Nunnally (1978) and Guilford (1954) criteria. After that, some descriptive analyses (separately by territories and together) and a comparison of means and samples are performed (Student's t-test, Wilcoxon signed- rank test, Mann-Whitney U test). At the same time, qualitative data are analysed to categorize the variables and indicators of the list in progress.

Although the questionnaire application has not produced substantial variations in the proposed indicators and variables, it has been useful to corroborate that the process helps to create learning. First of all, the PE participants' community knowledge remains constant through the process, while in the control group this variable obtains significantly lower values in the final questionnaire $(M=3,16$, $S D=0,5)$ in relation to the initial questionnaire $(M=3,36, S D=0,37) ; t(8)=2,5, p=0,04$. Secondly, the people involved in the $\mathrm{PE}$ process seems to know better the community participation after finishing the process $(M=8,2, S D=1,42) ; t(14)=-2,58, p=0,02$, in regarding the beforehand knowledge $(M=7,47$, $\mathrm{SD}=1,73$ ). Finally, in the global assessment of Community Development Plan there are important variations by the participants in the final questionnaire. Although at the beginning the PE participants and control group made a similar assessment, at the end involved people show a significant better assessment than the non-participants $(U=38, p=0,27)$. This suggests that collaborating in the evaluation boost a positive assessment of the community actions developed in the territory.

From the results of the open questions analysed it can be determined that the PE process has been relevant for involved people: (a) it has allowed to create a "powerful steering group"; (b) "oneself better knowledge"; (c) to know evaluation tools and group activities; and finally, (d) to give visibility to the work done and the strength behind the community projects. The participants' comments help us to demonstrate that they are aware of their own improvement and growth and support the advisability of variables and indicators such as community responsibility ("to boost 
contribuye a valorar positivamente las acciones comunitarias que se realizan en el territorio.

Del análisis de las respuestas abiertas de los cuestionarios, emerge que el proceso de EP ha sido relevante para las personas involucradas que manifiestan que: (a) ha permitido formar "un grupo motor potente"; (b) "conocer cosas de mí mismo"; (c) conocer herramientas de evaluación y dinámicas de grupo; y, por último, (d) visibilizar el trabajo hecho y la fuerza que hay detrás de los proyectos comunitarios. Los comentarios de los participantes permiten constatar que tienen conciencia de su propio progreso y crecimiento y confirman la pertinencia de indicadores y variables como responsabilidad comunitaria ("incrementar la implicación personal y el compromiso con el tejido social") y autoestima y conciencia de aprendizaje ("me ha demostrado que nunca es tarde para aprender y que puedo ser útil a los demás").

2.2.2. Análisis de las actas y las transcripciones de las reuniones comunitarias

De cada sesión del grupo motor, se toma nota y se redacta un acta completa en la que, además del relato principal de las aportaciones, se registran anotaciones de aspectos no verbales y observaciones a considerar sobre el progreso de las sesiones. Este material se completa con las transcripciones de las reuniones comunitarias (en algunas comunidades las sesiones son registradas audiovisualmente).

Las actas son el documento primario del que se extrae la información. Para el análisis del contenido se crea una matriz de Excel en la que se organiza la información de la siguiente manera: comunidad, documento principal, persona a la que se le atribuye la cita, cita, variable, signo e indicador. Además, se registra la asistencia de evaluadores universitarios, técnicos de la comunidad y vecinos en cada una de las reuniones.

Las unidades de análisis son párrafos o frases de las actas y su categorización es realizada por dos investigadores para reducir el riesgo de sesgo. Se llegan a identificar 321 unidades de análisis que se relacionan con las variables y los indicadores de empoderamiento propuestos. El objetivo es detectar en qué medida estas unidades de análisis se ponen de manifiesto en las reuniones, evolucionan y nos the personal implication and the social fabric compromise") and self-esteem and learning awareness ("it has shown me that is never late to learn and that I can be useful to the others").

2.2.2 Minutes analysis and community meetings transcripts

In each session of the steering group, a complete record is written in which along with the main contributions, some observations and notes of non-verbal aspects are registered during the session development. This material is completed with the community meetings transcripts (in some communities sessions are filmed).

The minutes are the basic document to obtain the information. An Excel matrix is created for their analysis. This matrix has the following distribution: community, primary document, person to whom the quote is attributed, quote, variable, sign and indicator. Moreover, the attendance of university evaluators, community technicians and neighbours in every meeting is registered.

The minutes' paragraphs or sentences are the analysis units and 2 researchers catalogue them, in order to reduce the bias risk. 321 units of analysis linked to the proposed empowerment indicators and variables are identified. The aim is to figure out how those analysis units state themselves in the meetings, evolve and provide us information on the set indicators.

The two researchers in charge of the analysis select together the units of each primary document 
aportan información sobre los indicadores establecidos.

Los dos investigadores encargados del análisis seleccionan conjuntamente las unidades de cada uno de los documentos principales y los categorizan, tomando como única referencia lo citado en el texto. Las citas se organizan en las diferentes variables e indicadores y estos últimos son convertidos en valores numéricos. Finalmente, se procede a una última revisión global para minimizar los errores.

Tras seleccionar las unidades de análisis y clasificarlas en las variables y dimensiones, se procede a realizar la enumeración de las mismas, mediante el programa SPSS. El registro se realiza por territorio y por documento, de manera que ha sido posible analizar la evolución global de todo el proceso de EP en cada una de las comunidades. Con ello se analiza la presencia o ausencia de variables e indicadores, su frecuencia, su dirección (indicadores positivos y negativos), el orden de aparición y la contingencia.

El análisis de contenido de las sesiones sugiere incorporar algún indicador nuevo (intuición sobre la realidad, dentro de la variable libertad) o la variable aprendizajes que permite recopilar la explicitación de un aprendizaje o la mejora en un conocimiento o habilidad, como consecuencia de la participación en el proceso de EP. Este análisis también pone en evidencia que algunos indicadores considerados como individuales, pueden tener una dimensión comunitaria y viceversa.

La variable que se manifiesta con más frecuencia es la libertad, seguida de la capacidad crítica y el conocimiento comunitario. Otras variables que destacan son autoestima (con aportaciones que denotan escasa autoestima), identidad comunitaria (indicadores: consciencia de trayectoria historia y cohesión social) y participación (indicadores: asistencia a proyectos comunitarios y generación o existencia de capital social). Además, en casos concretos, el análisis permite establecer algunos momentos clave en el proceso de empoderamiento, como pueden ser la presentación y análisis del mapa de acciones comunitarias, que da lugar a auto-evaluaciones de grupo acerca de las acciones pasadas y la situación actual de los proyectos; o la realización de una adaptación de la técnica DAFO, donde emergen los indicadores de autogestión, autoestima e iniciativa. and categorize them, taking as a sole reference what is given in the text. The quotes are organized in different variables and indicators and those are turned into numerical values. Finally, a final global revision to minimize the mistakes is performed.

After selecting the analysis units and classifying them into variables and dimensions, these are listed with SPSS program. In order to make possible the analysis of the global development of the PE process in every community, its registry is made by territory and document. We performed analysis of the presence or absence of variables and indicators, their frequency, direction (positive and negative indicators), their appearance order and contingency.

The content analysis of the sessions suggests adding some new indicators (intuition over reality, in the freedom's variable) or the learning's variable, which allows compiling new learning or the improvement of a knowledge or ability, as a result of the participation in the PE process. This analysis also shows that some indicators considered to be individual can have a community dimension and vice versa.

The more repeated variable is freedom, followed by critical capacity and community knowledge. Other variables that stand out are self-esteem (with contributions revealing little selfesteem), community identity (indicators: historical path awareness and social cohesion) and participation (indicators: community projects attendance and generation or existence of social capital). Besides, in specific situations, the analysis allows to set some key moments for the empowerment process, as the presentation and community map analysis, which derive into group self-evaluation over past actions and the current project situation; or the creation of an adapted FODA technique, where self-management, selfesteem and initiative indicators arise. 
2.2.3. Entrevistas semi-estructuradas a técnicos y vecinos de las comunidades

La última técnica aplicada para averiguar la evolución del empoderamiento individual y comunitario, son las entrevistas semi-estructuradas. Se realizan entrevistas a 14 vecinos y técnicos comunitarios de las tres comunidades-caso.

La duración de cada entrevista oscila entre los 15 y 45 minutos y se estructuran en 4 bloques: crecimiento y desarrollo de las capacidades personales, aportación del proceso de EP respecto a la identidad de la comunidad, fortalecimiento de las capacidades de la comunidad a partir de la participación en el proceso de EP y cambios que se han producido en las acciones comunitarias (en relación a la participación y a la capacidad de evaluar). Cada uno de estos bloques constituye una pregunta, que el entrevistador puede concretar en más sub-preguntas si lo considera. Los entrevistadores son diversos evaluadores universitarios, que disponen del mismo guión de entrevista y de un modelo único para tomar notas de campo.

Todas las entrevistas se graban y transcriben para su análisis, que se realiza con el programa de análisis cualitativo Atlas.ti. Dos investigadores realizan la codificación, de manera separada y posteriormente revisan conjuntamente sus categorizaciones. Utilizan la última versión del listado de variables e indicadores, considerando como códigos los indicadores y como familias de códigos las variables de empoderamiento.

El sistema de indicadores depurado permite recoger de manera más precisa las evidencias de empoderamiento en las palabras de los participantes de las EP. Destacamos que todas las variables emergen en el análisis en todos los territorios; excepto autoestima, que no aparece en el discurso de los participantes de un grupo motor, cuyo perfil es más técnico.

A raíz del análisis, se matizan algunas evidencias y se cambia la definición de algunos indicadores para adaptarlos mejor a las citas encontradas. Asimismo, se añade un indicador dentro de la variable de conocimiento comunitario para recoger aquellas aportaciones que manifiestan una mejora en el conocimiento del barrio o de la comunidad a nivel general o en su trayectoria histórica. $Y$ dentro de la variable de aprendizajes, se separa un indicador que hace referencia al conocimiento de mejoras en las capacidades personales de otros miembros de la comunidad.
2.2.3 Semi-structured interviews to technicians and community neighbours

The last applied technique to figure out the individual and community empowerment evolution is the semi-structured interview. Interviews to 14 neighbours and community technicians in the three studied communities are carried out.

The duration of each interview oscillate from 15 to 45 minutes and is divided into 4 sections: growth and development of personal capacities, contribution of the PE process to the community identity, strengthen of the community capacities through the PE process participation and changes developed in the community actions (related to the evaluation capacity and participation). Each of those sections constitutes a separate question, which the interviewer can develop into sub-questions. The interviewers are several university evaluators, with the same interview script and a unique model to take field notes.

All the interviews are recorded and transcribed for their analysis with the qualitative analysis program Atlas.ti. Two researchers made the codification separately and later on review its categorizations together. The last version of the variables and indicators list is employed, using its indicators as codes and the empowerment variables as code families.

The final indicator system helps us to compile more clearly the empowerment evidences from the PE participants' words. It is pointed out that all variables emerge from the analysis in all territories; except self-esteem, which does not appear in one steering group participants' discourse, possibility because they have a more technical profile.

After this analysis some evidences are modulated and some indicators' definitions are changed to adapt them better to the found quotes. Moreover, an indicator in the variable community knowledge is added, in order to collect the contributions showing an improvement of the district or community knowledge in general or in its historical path. And into the learning variable, an indicator related to the awareness of improvements on the personal capacity in other members of the community is isolated. 


\section{Resultados obtenidos: propuesta de sistema abierto de indicadores de empoderamiento}

Tras el análisis documental, la construcción de los indicadores de empoderamiento y el ensayo de dicho material en los estudios de caso realizados, el resultado es un sistema abierto de indicadores para analizar procesos de empoderamiento.

Este sistema está compuesto por 13 variables de empoderamiento y 36 indicadores, la mayoría de ellos con dimensión individual y comunitaria, lo que configura una propuesta final de 58 indicadores. Esta clasificación se obtiene a partir de los resultados emergentes de los análisis del empoderamiento en el estudio de casos, que indican que un mismo concepto -como la responsabilidad- se puede aplicar tanto a la dimensión personal al asumir tareas y compromisos, como a los compromisos del grupo y de la comunidad que hacen referencia a la voluntad y capacidad de actuar colectivamente, consciente de la corresponsabilidad de las acciones que se desarrollan. En la tabla 2, presentamos el sistema de indicadores resultante.

\section{Discusión de resultados y conclusiones}

La propuesta final que se presenta se concibe como un sistema abierto de indicadores de empoderamiento. Se trata de un sistema porque entendemos que el empoderamiento es un concepto multidimensional, en el cual están interrelacionados los diferentes componentes que constituyen las variables. Una valoración justa y comprensiva del empoderamiento requiere la consideración y valoración de todos estos aspectos.

El sistema se concibe como "abierto", y en permanente revisión, porque requiere el contraste y la confrontación con nuevas prácticas y experiencias que permitan mejorarlo. Contrastar resultados y discutir límites, enfoques o matices es, en buena medida, una tarea pendiente y de enorme importancia para los programas y proyectos socioeducativos y de acción comunitaria. La aportación más significativa en esta investigación ha sido comenzar a delimitar y definir el alcance y los términos de lo que configuran las experiencias empoderadoras.

La propuesta final se construye a partir de la revisión bibliográfica y documental de las aportaciones existentes. A partir de esta contrastación biblio-

\section{Obtained results: open system of empo- werment indicators' proposal}

Once the documental analysis was made, the empowerment indicators are built and the testing of that material in the case studies is undergone, the result is an open system of indicators to analyse the empowerment processes.

This system contains 13 empowerment variables and 36 indicators, most of them with an individual and community dimension, which creates a final proposal of 58 indicators. This classification is obtained from the emerging results of the empowerment analysis in the case studies, which indicate that the same concept (such as responsibility) can be applied both in a personal dimension (assuming tasks) and on a community level (will and collective action, being aware of the shared responsibility of the actions developed). In table 2, we show the resulting indicator's system.

\section{Results and conclusions discussion}

The final proposal is created as an open system of empowerment indicators. It is a system because we understand empowerment as a multidimensional concept, in which several components constituting the variables are interrelated. An adequate and comprehensive evaluation of empowerment requires all those aspects' consideration and assessment.

It is considered as an "open" system, and constantly changing, because it needs the contrast and confrontation of new practices and experiences in order to improve. Contrasting results and discussing limits, approaches or details, is a pending task and of an extreme importance for the socio-educative projects in community actions. The most important contribution of this research was to start delimiting and defining the scope and the terms of what the empowerment experiences are.

The final proposal is built over the existing contributions' bibliographical and documental revision. From this bibliographical contrast, most indicators have been validated. Among them: security (Altogether Better, 2010), bravery (Holte-Mc Kenzie, Fordes, \& Theobald, 2006), shyness (Holte-Mc Kenzie, 
Tabla 2. Variables e indicadores de empoderamiento

\begin{tabular}{|c|c|c|c|}
\hline \multirow[t]{2}{*}{ Variable } & \multirow[t]{2}{*}{ Indicador } & \multicolumn{2}{|c|}{ Dimensiones } \\
\hline & & Ind & Com \\
\hline \multirow{4}{*}{ Autoestima } & Progreso en la satisfacción con uno mismo & $x$ & \\
\hline & Coraje (Afrontar con seguridad determinadas acciones y compromisos) & $x$ & \\
\hline & Timidez (Capacidad de mostrarse en público sin temor) & $x$ & \\
\hline & Seguridad (Creer en uno mismo) & $x$ & \\
\hline \multirow{3}{*}{ Responsabilidad } & Asumir tareas y compromisos de forma consciente voluntaria y realista & $x$ & $x$ \\
\hline & Asumir un rol propio & $x$ & $x$ \\
\hline & Capacidad de actuar comunitariamente & & $x$ \\
\hline \multirow{2}{*}{ Eficacia } & Capacidad de tomar decisiones apropiadas en los momentos oportunos & $x$ & $x$ \\
\hline & Mantener un sistematismo y continuidad en la realización de tareas (Disciplina) & $x$ & $x$ \\
\hline \multirow{2}{*}{ Capacidad crítica } & Capacidad de análisis & $x$ & $x$ \\
\hline & Tener un criterio propio & $x$ & $x$ \\
\hline \multirow{2}{*}{ Autonomía } & Iniciativa & $x$ & $x$ \\
\hline & Autogestión & $x$ & $x$ \\
\hline \multirow{2}{*}{ Reconocimiento } & Considerarse como interlocutor válido y actor & $x$ & $x$ \\
\hline & Considerar a los demás como interlocutores válidos y actores & $x$ & $x$ \\
\hline \multirow{3}{*}{ Trabajo en equipo } & Mostrar implicación en el trabajo en equipo & $x$ & \\
\hline & Contribuir con un rol proactivo en el trabajo en equipo & $x$ & \\
\hline & Capacidad de comunicación & $x$ & $x$ \\
\hline \multirow{2}{*}{$\begin{array}{l}\text { Inclusión e integra- } \\
\text { ción comunitaria }\end{array}$} & Capacidad de integración de la comunidad o del grupo & & $x$ \\
\hline & Acogida de nuevos residentes & & $x$ \\
\hline \multirow{2}{*}{$\begin{array}{l}\text { Identidad } \\
\text { comunitaria }\end{array}$} & Sentimiento de pertenencia a la comunidad o al grupo & $x$ & $x$ \\
\hline & Conciencia de problemáticas compartidas & $x$ & $x$ \\
\hline \multirow{3}{*}{$\begin{array}{l}\text { Conocimiento } \\
\text { comunitario }\end{array}$} & Conocimiento general de la comunidad & $x$ & $x$ \\
\hline & Conocimiento de servicios, recursos y equipamientos de la comunidad & $x$ & $x$ \\
\hline & Conocer los diferentes agentes y organizaciones de la comunidad. & $x$ & $x$ \\
\hline \multirow{6}{*}{$\begin{array}{l}\text { Organización de } \\
\text { la comunidad }\end{array}$} & Capacidad de la comunidad para organizarse & & $x$ \\
\hline & Circulación fluida de información en la comunidad & & $x$ \\
\hline & Capacidad de respuesta comunitaria & & $x$ \\
\hline & Capacidad de trabajar en alianzas & & $x$ \\
\hline & Participación de personas y grupos & $x$ & $x$ \\
\hline & Creación o disposición de espacios para la participación & & $x$ \\
\hline \multirow{2}{*}{ Aprendizajes } & Consciencia de haber adquirido o mejorado los propios conocimientos o capacidades & $x$ & $x$ \\
\hline & Mejora de las capacidades de los demás & $x$ & $x$ \\
\hline \multirow{3}{*}{ Evaluación } & Capacidad de evaluación & $x$ & $x$ \\
\hline & Importancia de la evaluación & $x$ & $x$ \\
\hline & Capacidad de autoevaluación & $x$ & $x$ \\
\hline
\end{tabular}

Ind: dimensión individual

Com: dimensión comunitaria

Fuente: elaboración propia. 
Table 2. Empowerment variables and indicators

\begin{tabular}{|c|c|c|c|}
\hline \multirow[t]{2}{*}{ Variable } & \multirow[t]{2}{*}{ Indicator } & \multicolumn{2}{|c|}{ Dimensions } \\
\hline & & Ind & Com \\
\hline \multirow{4}{*}{ Self-esteem } & Self satisfaction progress & $x$ & \\
\hline & Bravery (To face with determination some actions and compromises) & $x$ & \\
\hline & Shyness (Ability to face public without fear) & $x$ & \\
\hline & Security (To believe in oneself) & $x$ & \\
\hline \multirow{3}{*}{ Responsibility } & To assume voluntarily and realistically tasks and compromises & $x$ & $x$ \\
\hline & To assume oneself role & $x$ & $x$ \\
\hline & Capacity for community actions & & $x$ \\
\hline \multirow{2}{*}{ Efficacy } & Capacity to make decisions in the right moments & $x$ & $x$ \\
\hline & Be systemic and constant in the task performance & $x$ & $x$ \\
\hline \multirow{2}{*}{ Critic capacity } & Analysis capacity & $x$ & $x$ \\
\hline & Have own criteria & $x$ & $x$ \\
\hline \multirow{2}{*}{ Autonomy } & Initiative & $x$ & $x$ \\
\hline & Self-management & $x$ & $x$ \\
\hline \multirow{2}{*}{ Acknowledgment } & Consider oneself as an actor and valid interlocutor & $x$ & $x$ \\
\hline & Consider the others as actors and valid interlocutors & $x$ & $x$ \\
\hline \multirow{3}{*}{ Team working } & To show team working implication & $x$ & \\
\hline & To contribute with a proactive role in the team working & $x$ & \\
\hline & Communication capacity & $x$ & $x$ \\
\hline \multirow{2}{*}{$\begin{array}{l}\text { Inclusion and com- } \\
\text { munity integration }\end{array}$} & Capacity to integrate the community or group & & $x$ \\
\hline & New residents welcome & & $x$ \\
\hline \multirow{2}{*}{$\begin{array}{l}\text { Community } \\
\text { identity }\end{array}$} & Community or group feeling & $x$ & $x$ \\
\hline & To be aware of the shared problems & $x$ & $x$ \\
\hline \multirow{3}{*}{$\begin{array}{l}\text { Community } \\
\text { knowledge }\end{array}$} & Community general knowledge & $x$ & $x$ \\
\hline & Community services, resources and equipment knowledge & $x$ & $x$ \\
\hline & Knowledge of the community agents and organizations & $x$ & $x$ \\
\hline \multirow{6}{*}{$\begin{array}{l}\text { Community } \\
\text { organization }\end{array}$} & Organization capacity & & $x$ \\
\hline & Fluid information flow in the community & & $x$ \\
\hline & Community response capacity & & $x$ \\
\hline & Alliance working capacity & & $x$ \\
\hline & Person and group participation & $x$ & $x$ \\
\hline & Participation areas creation or disposition & & $x$ \\
\hline \multirow{2}{*}{ Learning } & To be aware of having acquire or improve oneself capacities or learning & $x$ & $x$ \\
\hline & Improvement of the other capacities & $x$ & $x$ \\
\hline \multirow{3}{*}{ Evaluation } & Evaluation capacity & $x$ & $x$ \\
\hline & Evaluation relevance & $x$ & $x$ \\
\hline & $\overline{\text { Self-evaluation capacity }}$ & $x$ & $x$ \\
\hline
\end{tabular}

Ind: individual dimension

Com: community dimension

Source: authors' 
gráfica, se han validado la mayoría de indicadores. Entre ellos: seguridad (Altogether Better, 2010), coraje (Holte-Mc Kenzie, Fordes \& Theobald, 2006), timidez (Holte-Mc Kenzie, Fordes \& Theobald, 2006), asumir tareas y compromisos de forma consciente, voluntaria y realista (Fetterman \& Wandersman, 2007), mejora o adquisición de capacidades y conocimientos (Fetterman \& Wandersman, 2007), progreso en la satisfacción con uno mismo (Holte-Mc Kenzie, Fordes \& Theobald, 2006), capacidad de evaluación (Miller \& Campbell, 2006), capacidad de actuar comunitariamente (Miller \& Campbell, 2006), capacidad de la comunidad para organizarse (Miller \& Campbell, 2006), capacidad de trabajar en alianzas (Newman, 2008). La propuesta incluye los llamados "mediadores psicológicos" según Maton (2008): sentimiento de pertenencia y conciencia; aspectos como la autoestima y los sentimientos subjetivos de empoderamiento, ya evidenciados por CDX (2008) como cruciales para el empoderamiento, tanto individual como comunitario; y se consideran todos aquellos atributos que pueden relacionarse con la capacidad organizativa de la comunidad (social capacity building) puesto que se trata de una dimensión estrechamente relacionada con el empoderamiento y con un significativo recorrido (Lennie, 2005). Junto con esta dimensión se incluyen indicadores vinculados con la fluidez en la información o la capacidad de trabajar en alianzas, negociar, consensuar y construir sinergias entre diversos actores de la comunidad.

El sistema propone indicadores poco habituales en las formulaciones realizadas hasta ahora, pero han sido validados a través de los estudios de caso realizados en esta investigación. Entre ellos cabe citar: asumir tareas y compromisos de forma consciente, voluntaria y realista; considerarse y considerar a los otros como interlocutores válidos y actores, o consciencia de problemáticas compartidas.

La propuesta presentada requiere adaptarse a los diferentes contextos culturales y ámbitos de aplicación, puesto que no existe una medida universal del empoderamiento. Esta concepción de sistema se asemeja a la idea de una matriz generadora de indicadores de empoderamiento que ha de configurarse en cada momento, según el contexto y el objetivo específico a evaluar. Entendemos, pues, que estos indicadores no pueden aplicarse a cual-
Fordes \& Theobald, 2006), to assume tasks and compromises voluntarily and realistically (Fetterman \& Wandersman, 2007), capacities and knowledge improvement or acquisition (Fetterman \& Wandersman, 2007), self-satisfaction process (Holte-Mc Kenzie, Fordes \& Theobald, 2006), evaluation capacity (Miller \& Campbell, 2006), community action capacity (Miller \& Campbell, 2006), community organization capacity (Miller \& Campbell, 2006), alliance working capacity (Newman, 2008). The proposal includes Maton's (2008) "psychological mediators", a feeling of pertinence and coincidence; aspects such as self-esteem and subjective empowerment feelings, were already evidenced as crucial for empowerment (individual and community) by CDX (2008); and all attributes that can be related to the community organizational capacity (social capacity building) are considered due to its close relation to empowerment and a significant itinerary (Lennie, 2005). Along with this dimension, indicators linked to information fluidity or alliance working capacity, negotiation and building synergies among the community actors are included.

The system proposes some currently unusual indicators in its formulations, but they have been certified through the case studies performed on this research. Among them, we must mention: to assume voluntarily and realistically tasks and compromises; to consider oneself and the others as valid interlocutors and actors, or to be aware of the shared problems.

The presented proposal requires an adaptation to the different cultural contexts and application areas, because there is no universal empowerment measure. This system conception is similar to the idea of an empowerment indicator-generating matrix that every time must be configured regarding the context of specific assessed goal. Accordingly, we understand that those indicators cannot be applied to any territory and process, without taking into account a specific community's peculiarities and without a dialogue with all the parts involved in order to select, adapt and design accurate indicators for that community (Morrissey, 2000). Probably, an ultimate and universal system is not possible; but as we have said before, some empowerment indicators are more universal than others.

Any educational or participative process can use 
quier territorio y proceso, sin tener en cuenta las peculiaridades de la comunidad concreta y sin un diálogo con todas las partes interesadas para seleccionar, adaptar y diseñar indicadores apropiados para esa comunidad (Morrissey, 2000). Probablemente, no pueda existir un sistema definitivo y universal; pero como ya se ha comentado anteriormente, algunos indicadores de empoderamiento son más universales que otros.

Cualquier proceso educativo o participativo puede utilizar o tener presente este sistema de indicadores para evaluar y detectar empoderamiento. Con todo, hay que recordar que esta aportación se ha configurado a partir del análisis de procesos de Evaluación Participativa. La interpretación en otros ámbitos o contextos seguramente no diferirá, pero hay que tener presente este sesgo en el diseño de la propuesta. Es por ello que la aplicación en otros escenarios ha de permitir validar, pautar y contrastar el sistema.

El potencial de este sistema de indicadores radica en el conjunto de indicadores y en los análisis, estudios y proyectos que a partir de esta propuesta puedan hacerse. Se trata de un punto de partida para posteriores investigaciones, validaciones o reformulaciones. Por ello, puede ser de gran utilidad para mejorar aquellas propuestas y proyectos que tengan como objetivo incidir en el fortalecimiento y la autonomía de las personas y comunidades. En definitiva, el sistema puede ayudar a reforzar enormemente el discurso y el valor de las acciones socioeducativas y el trabajo comunitario. or bear in mind this indicator system in order to evaluate and detect empowerment. We must recall that this contribution is based on Participatory Evaluation. Its interpretation in other fields should not be distant but we must be aware of this bias in the proposal design. That is why its appliance to other areas must allow the assessment, rule and contrast of the system.

The indicator system's potential comes from the group of indicators and its analysis, studies and projects that may be made from this proposal. It is a starting point for later researches, validations or reformulations. This is the reason why it can be very useful for improving projects or proposals aiming to strengthen or given more autonomy to people and communities. To sum up, this system can help to support the discourse and value of socio-educational actions and community work.

\section{Referencias bibliográficas/Bibliographic References}

Adamson, D. \& Bromiley, R. (2008). Community empowerment in practice: Lessons for Communities First. United Kingdom. American Journal of Evaluation, 27(3), 296-319.

Alsop, R., Frost, M. \& Holland, J. (2006). Empowerment in practice. From analysis to implementation. Washington: The World Bank.

Altogether Better (2010). Voices from experience. Empowering Communities to Improve their Health and Well-Being. Recuperado de: http://www.altogetherbetter.org.uk/SharedFiles/Download.aspx?pageid $=36 \&$ mid=57\&fileid $=25$

Bacqué, M.H. \& Biewener, C. (2013). L'empowerment, une practique émancipatrice. París: La Découverte.

Bowers, A. (2004). Start at the end: empowerment evaluation product planning. Evaluation and Program Planning, 27(3), 275-285. Doi:10.1016/j.evalprogplan.2004.04.002

CDX (2008). Empowering evaluation: evaluating empowerment. A practice sharing report from CDX. Recuperado de: http://www.cdf.org.uk/nep-microsite/files/resources/Guidance/Empowering\%2Oevaluation\%20evaluating\%20empowerment.pdf 
Coller, X. (2000). Estudio de casos. Cuaderno No 30. Madrid: Centro de investigaciones sociológicas (CIS).

Díaz-Puente, J., Cazorla, A. \& De los Ríos, I. (2009). Empowering communities through evaluation: some lessons from rural Spain. Community Development Journal, 44(1), 53-68. Doi: 10.1093/cdj/bsmo08

Fetterman, D. \& Wandersman, A. (2007). Empowerment evaluation: Yesterday, Today and Tomorrow. American Journal of Evaluation, 28,179-198. Doi: 10.1177/1098214007301350

Freire, P. (1987). La educación como práctica de la libertad (37 edición). México: Siglo XXI.

Freire, P. (1988). Pedagogía del oprimido (11 edición). Madrid: Siglo XXI.

Gaventa, J. (2003). Towards participatory local governance: Assessing the transformative possibilities. Comunicación presentada en Conference on Participation: FromTyranny to Transformation, Manchester, 27-28 Febrero.

Gil, E., Heras P. \& Llena, A. (2013). Evaluación participativa y empoderamiento: Análisis documental de investigaciones y prácticas. Depósito digital de la UB. Disponible en:

http://hdl.handle.net/2445/50669

Guilford, J.P. (1954). Psychometric methods. New York: McGraw Hill.

Holte-Mc Kenzie, M., Fordes, S. \& Theobald, S. (2006). Development of a participatory monitoring and evaluation strategy. Evaluation and Program Planning, 29(4), 365-376. Doi: 10.1016/j.evalprogplan.2006.08.007

Hombrados-Mendieta, M. I. \& Gómez-Jacinto, L. (2001). Potenciación en la intervención comunitaria. Intervención Psicosocial, 10(1), 55-69.

INTRAC (1999). Seguimiento y evaluación del empoderamiento. Documento de consulta. Recuperado de: http://www.google.es/url?sa=t\&rct=j\&q=\&esrc=s\&source=web\&cd=1\&ved=oCDUQFjAA\&url=http\%3A\%2F\% 2Fwww.impactalliance.org\%2Ffile_download.php\%3Flocation\%3DS_U\%26filename\%3D11970512111seguimiento_y_evaluaci\%27on_del_empoderamiento.pdf\&ei=JoNpUp7cOMWyhAfh4IGQCw\&usg=AFQjCNGAvouUZBqMKf-VzUO7idgK2BysWQ\&sig2=R57sUWKJFwrsbFl5dj9NWA\&bvm=bv.55123115,d.ZG4

Jennings, L.B., Parra-Medina, D.M., Hilfinger, D.K, \& McLoughlin, K. (2013). Toward a Critical Social Theory of Youth Empowerment. Journal of Community Practice, 14(1-2), 31-35. Doi: 10.1300/J125v14nO1_03

Laverack, G. (2001) An identification and interpretation of the organizational aspects of community empowerment. Community Development Journal, 36(2), 134-145. Doi: 10.1093/cdj/36.2.134

Laverack, G. (2005). Using a 'domains' approach to Guild community empowerment. Community Development Journal, 14(1), 4-12. Doi:10.1093/cdj/bsio38

Lennie, J. (2005). Empowering and Disempowering Impacts. An Evaluation Capacity-Building Process for Sustainable Community IT. Evaluation, 11(4), 390-414

Luttrell, C., Quiroz, S., Scrutton, C. \& Bird, K. (2009). Understanding and operationalising empowerment. London: Overseas Development Institute (ODI).

Malhotra, A., Shuler, S.R. \& Boender, C. (2002). Measuring Women's Empowerment as a Variable in International Development. Paper para el World Bank Workshop on Poverty and Gender: New perspectives. Recuperado de http://www4.worldbank.org/afr/ssatp/Resources/HTML/GenderRG/Source\%20\%2Odocuments/ Technical\%2OReports/Gender\%2OResearch/TEGEN5\%2OMeasuring\%2OWomen's\%20Empowerment\%2OICRW\%2O2OO2.pdf

Maton, K.I. (2008). Empowering, Community Settings: Agents of Individual Development, Community Betterment, and Positive Social Change. American Journal of Community Psychology, 41(1-2), 4-21. Doi: $10.1007 / \mathrm{s} 10464-007-9148-6$

Miller, R.L. \& Campbell, R (2006). Taking stock of empowerment evaluation: An empirical review. American Journal of Evaluation, 27: 296-319.

Morrisey, J. (2000). Indicators of citizen participation: lessons from learning teams in rural EZ/EC communities. Community development journal, 35(1), 59-74. Doi: 10.1093/cdj/35.1.59

Mosedale, S. (2003). Towards A Framework For Assessing Empowerment. Paper presentado en International Conference New Directions in Impact Assessment for Development: Methods and Practice, University of Manchester UK, 24-25 Noviembre.

[ 74 ] PERE SOLER, ANNA PLANAS, ANNA CIRASO-CALÍ Y ARANTXA RIBOT-HORAS 
Newman, K. (2008). Whose view matters? Using participatory processes to evaluate Reflect in Nigeria. Community Development Journal, 43, 382-394

Nunnally, J.C. (1978). Psychometric theory. New York: MacGrw-Hill.

Paxton, R. J., Valois, R. F. \& Drane, J. W. (2005). Perceived Youth Empowerment: Reliability and validity of a brief scale. American Journal of Health Studies, 20(3/4), 186-193.

Pick, S., Sirkin, J., Ortega, I., Osorio, P., Xocolotzin, U. \& Givaudan, M. (2007). Escala Para Medir Agencia Personal y Empoderamiento (ESAGE). Revista Interamericana de Psicología, 41(3), 295-304.

Plottu, B. \& Plottu, E. (2009). Approaches to participation in evaluation: some conditions for Implementation. Evaluation, 15(3), 343-359. Doi: 10.1177/1356389009106357

Rappaport, J. (1981). In praise of paradox: a social policy of empowerment over prevention. Presidential address to the Division of Community Psychology of the American Psychological Association. American Journal of Community Psychology, 9, 1-25. Doi: 10.1007/BFoo896357

Rappaport, J. (1985). The power of empowerment language. Social Policy, 16, 15-21.

Rappaport, J. (1986). Collaboration form empowerment: Creating the language of mutual help. En Boyte, H., \& Riessman, F. (Eds). The new Populism: The politics of empowerment. Philadelphia: Temple University Press.

Rappaport, J. (1987). Terms of Empowerment/Exemplars of Prevention: Towards a Theory for Community Psychology. American Journal of Community Psychology, 15(2), 121-147. Doi: 10.1007/BFo0919275

Rowlands, J. (1997). Questioning empowerment: Working with women in Honduras. Oxford, UK: Oxfam.

Rutherford, F.P. \& Lewis, H.M. (1997). McDowell County, West Virginia enterprise community: a report on the learning team's assessment of EC progress. Volume VIII in Community Partnership Center 1998, Rural Empowerment Zones and Enterprise Communities: Lessons from the CPC Learning Initiative. Knoxville, TN: University of Tennessee.

Sadan, E. (1997). Empowerment and Community Planning: Theory and Practice of People-Focused Social Solutions. Tel Aviv: Hakibbutz Hameuchad Publishers.

San Pedro, P. (2006). El individuo como agente de cambio: El proceso de empoderamiento. Desarrollo "En Perspectiva", 01, 1-8.

Sen, G., \& Grown, C. (1988). Development, Crises and Alternative Visions. London: Earthscan Publications Limited. Doi: 10.2307/1967063

Stake, R.E (1998). Investigación con estudio de casos. Madrid: Ediciones Morata.

Suarez-Balcazar, Y. \& Harper, G. (Edits.) (2004). Empowerment and participatory evaluation of community interventions: Multiple benefits. Binghamton: The Haworth Press., Inc.

Themessl-Huber, M.T. \& Grutsch, M.A. (2003). The shifting locus of control in participatory evaluations. Evaluation, 9(1), 92-111. Doi: 10.1177/1356389003009001006

Titterton, M. \& Smart, H. (2008). Can participatory research be a route to empowerment? A case study of a disadvantaged Scottish community. Community Development Journal, 43(1), 52-65. Doi: $10.1093 / \mathrm{cdj} / \mathrm{bs}$ lo37

Tromp, M. (2007).. A system of empowerment indicator for a corporate work environment. Johannesburg: University of Johannesburg.

Úcar, X., Heras, P. \& Soler, P. (2014). La Evaluación Participativa de acciones comunitarias como metodología de aprendizaje para el empoderamiento personal y comunitario. Pedagogía Social. Revista Interuniversitaria, 24.

Varela Crespo, L. (2010). La educación social y los servicios sociales en los procesos de desarrollo comunitario: revitalización del trabajo en red. Pedagogía Social. Revista Interuniversitaria, 17, 137-148.

Vidal, F. (2009). Pan y rosas. Fundamentos de exclusión social y empoderamiento. Madrid: Cáritas y Fundación Foesa.

Zimmerman, M.A. (1995). Psychological Empowerment: Issues and illustrations. American of Community Psychology, 23(5), 581-599. Doi: 10.1007/BF02506983 


\section{Notas/ Notes}

1 "La evaluación participativa de acciones comunitarias como metodología de aprendizaje para el empoderamiento individual y comunitario". EDU2O10-15122 (Subprograma EDUC). Ministerio de Ciencia e Innovación, Gobierno de España. IP: Xavier Úcar. Equipo de investigación: Anna Ciraso, Estefanía Crespo, Héctor Núñez y Pilar Pineda (Universitat Autònoma de Barcelona); Anna Planas y Pere Soler (Universitat de Girona); Esther Gil, Pilar Heras y Asun Llena (Universitat de Barcelona); Laia Sánchez (Citilab). Con colaboración de: Jordi Colobrans, Arantxa Ribot y Jordi Rieradevall.

2 "The participatory evaluation of community actions as learning methodologies for the personal and community empowerment". EDU2010-15122 (Subprogram EDUC). Ministry for Sciences and Innovation, Spanish Government. IP: Xavier Úcar. Research team: Anna Ciraso, Estefanía Crespo, Héctor Núñez and Pilar Pineda (Universitat Autònoma de Barcelona); Anna Planas and Pere Soler (Universitat de Girona); Esther Gil, Pilar Heras and Asun Llena (Universitat de Barcelona); Laia Sánchez (Citilab). With the collaboration of: Jordi Colobrans, Arantxa Ribot and Jordi Rieradevall.

\section{CÓMO CITAR ESTE ARTÍCULO / HOW TO CITE THE ARTICLE:}

Soler, P., Planas, A., Ciraso-Calí, A. \& Ribot-Horas. A. (2014). Empoderamiento en la comunidad. El diseño de un sistema abierto de indicadores a partir de procesos de Evaluación Participativa. Pedagogía Social. Revista Interuniversitaria, 24 4977. doi:10.7179/PSRI_2014.24.03

Soler, P., Planas, A., Ciraso-Calí, A. \& Ribot-Horas. A. (2014). Empowerment in the community. The design of an open indicators system from Participatory Evaluation processes. Pedagogía Social. Revista Interuniversitaria, 24 49-77. doi:10.7179/PSRI_2014.24.03

Fecha de recepción del artículo / received date: 16.1.2014

Fecha de revisión del artículo / reviewed date: 27.I.2014

Fecha de aceptación final / accepted date: 31.111.2014

\section{DIRECCIÓN DE LOS AUTORES/ AUTHOR'S ADDRESS:}

Pere Soler y Anna Planas-Lladó. Departamento de Pedagogía, Universitat de Girona

SantDomènec, 9, 17071, Girona. Dirección de correo /e-mail anna.planas@udg.edu pere.soler@udg.edu.

Arantxa Ribot y Anna Ciraso-Calí: Despacho G6/215, Facultat de Ciències de l'Educació, 08193 Campus de la UAB (Bellaterra). Dirección de correo /e-mail arantxa.ribot@uab.cat anna.ciraso@uab.cat

\section{PERFIL ACADÉMICO / ACADEMIC PROFILE:}

Pere Soler. Profesor en el Departamento de Pedagogía de la Universidad de Girona y director del Programa Conjunto de Máster en Juventud y Sociedad. Miembro del grupo de investigación Políticas, Programas y Servicios Socioculturales y Educativos del Instituto de Investigación Educativa de la Universidad de Girona. Su docencia e investigación se centran en la pedagogía social a través del desarrollo de la comunidad, la política de juventud y asociaciones de niños y jóvenes. Ha coescrito una serie de artículos sobre estas áreas. Sus contribuciones se pueden encontrar en :http://www.udg.edu/professorat/Planapersonal/tabid/8656/ID/2000485/language/en-US/Default.aspx

Anna Planas-Lladó. Doctora en Pedagogía (2009) por la Universidad de Girona. Profesora en el Departamento de Pedagogía de la Universidad de Girona. Miembro del grupo de investigación sobre Políticas, Programas y Servicios socioculturales y educativos del Instituto de Investigación Educativa de la Universidad de Girona. Su investigación se ha centrado en la animación sociocultural, la evaluación participativa y las políticas de juventud. Tiene experiencia profesional en el ámbito de la animación sociocultural, el trabajo juvenil y el desarrollo de proyectos socioeducativos. Sus contribuciones pueden consultarse en: http://www.udg.edu/personal/anna.planas.llado/tabid/8656/default.aspx?ID=2000956 
Anna Ciraso-Calí. Pedagoga (por la UAB) e investigadora, miembro del grupo de investigación GIPE (Grupo Interdisciplinar de Políticas Educativas). En el ámbito profesional, tiene experiencia en educación no formal, especialmente en educación ambiental, en talleres expresivos y lúdicos; y como educadora profesional en el apoyo pedagógico de estudiantes y familias. Sus líneas de investigación se centran en la formación y en su evaluación, en la evaluación de la transferencia de los aprendizajes, en el empoderamiento y la evaluación participativa de acciones comunitarias.

Arantxa Ribot. Licenciada en pedagogía por la Universidad de Barcelona, ha cursado dos posgrados, el primero en acogida, adopción y postadopción en la Universitat Ramón Llull y el segundo en educación emocional y bienestar en la Universitat de Barcelona. En 2012 obtuvo el título de máster en investigación e innovación en educación por la UNED. Actualmente está cursando un segundo máster en medición del comportamiento y de la salud y el doctorado en inteligencia emocional y salud mental. Ha orientado su actividad investigadora hacia el área de la salud mental, la educación emocional y la evaluación de programas. Es técnica superior de investigación en la Universidad de Barcelona y trabaja como pedagoga en el Hospital Sant Juan de Dios. 